\title{
Of Medicine, Race, and American Law: The Bubonic Plague Outbreak of 1900
}

\section{Chasples McClain}

In March of 1900 several cases of bubonic plague were discovered in San Francisco's Chinatoun. In response the health authorities, at the instance of the Surgeon General of the United States, sought to implement a series of extraordinarily coercive measures aimed at the city's Asian inhabitants. The measures provoked an uproar among the Chinese, and they determined to challenge them in the federal Circuit Court for the Northern District of California. This essay, based on extensive research in court records, the archives of the U.S. Public Health Service, and press accounts in English and Chinese, documents the complex events that gave rise to the cases of Wong Wai v. Williamson and Jew Ho v. Williamson and the cases themselves as they unfolded in the courts. The cases raised new and difficult questions of fact and of law and tested as few other cases have before or since a court's capacity to act as arbiter between individual rights (and the rights of an ostracized minority at that) and the public interest in a period of acute health emergency.

In the spring of 1900 several cases of bubonic plague were detected in the Chinese quarter of San Francisco. In response, the federal and local health authorities sought to implement a series of measures unparalleled in

Charles McClain is vice chairman of the Jurisprudence and Social Policy Program and lecturer, School of Law (Boalt Hall), University of California, Berkeley. Ph.D. 1972, Stanford University; J.D. 1974, Hastings College of the Law, University of California.

The author wishes to thank Professor Sucheng Chan, University of California, Santa Cruz; Professor Joseph Grodin, University of California, Hastings College of the Law; Professor Kristin Luker, University of California, Berkeley; Professor Laurene Wu McClain, City College of San Francisco; and anonymous reviewers for reading and commenting on an earlier draft of this paper. He is particularly indebted to Professor Bernard Diamond, University of California, Berkeley, for his detailed comments on the text. It goes without saying that any failings that remain in the piece are the author's own.

(C) 1988 American Bar Foundation 
the annals of American medicine. These measures-the mass inoculation of the city's Chinese and Japanese inhabitants with an experimental vaccine, the quarantining of the entire population of Chinatown-quickly embroiled them in deep and bitter controversy, a controversy that came eventually to involve the governor of California, the founder of the laboratory that later became the National Institutes of Health, the surgeon general of the United States, the U.S. secretary of state, and the ambassadors of China and Japan. The matter had eventually to be resolved by the courts.

This essay examines the events surrounding the first outbreak of plague in the continental United States and the important federal cases that grew out of those events. The cases, Wong Wai $v$. Williamson ${ }^{1}$ and Jew Ho v. Williamson, ${ }^{2}$ confronted the judiciary with novel and acutely difficult questions of fact and of law. To study them and the background out of which they grew is to learn something of importance about the history of American law, about the history of the Chinese community in this country, and about the ideas and attitudes of the American medical and public health establishment at the turn of the century, a subject of rich scholarly speculation in recent years. ${ }^{3}$ It is also, I submit, to learn something of perhaps enduring significance about the capacity of courts to intervene in public health crises and shape responses to them. What lessons the episode described here may have to teach us in our efforts to deal with the great health emergency that we now confront, the AIDS epidemic, I shall leave to the reader to decide. That in their raw elements the two health crises demonstrate certain striking parallels-the sudden appearance on American soil of a strange, dread disease affecting mainly a stigmatized social group and the consideration of novel and drastic measures as a means of dealing with the outbreak-seems undeniable. ${ }^{4}$

Before chronicling the extraordinary and complex episode that began to unfold in March 1900, however, we must say a word first about the disease called bubonic plague and its most recent appearance in epidemic form on the world scene. It is also necessary to say something about the 19th-century Chinese immigration to California and the reaction that it provoked.

1. Wong Wai v. Williamson, 103 Fed. Rep. 1 (1900).

2. Jew Ho v. Williamson, 103 Fed. Rep. 10 (1900).

3. I have in mind such works as Paul Starr's The Social Transformation of American Medicine (1982) and the commentary it has provoked. See also K. Luker, Abortion and the Politics of Motherhood (1984).

4. That there are notable differences as well should also be apparent. 


\section{ON BUBONIC PLAGUE}

The word "plague" is freighted with dark significance and has been used loosely over the centuries to refer to almost any epidemic disease attended with high mortality. In modern times the term refers exclusively to the ailment caused by the bacterium now called yersinia pestis. Plague can manifest itself in any of a number of forms, but historically the most important form of the disease has undoubtedly been bubonic plague, a terrifying malady with classic clinical symptoms. A patient infected with the bubonic plague microorganism initially experiences a sudden onset of fever, chills, weakness, and severe headache. Soon the lymph nodes of the groin, neck, and armpits, the parts of the body in which the plague bacteria first proliferate, swell dramatically, at times reaching the size of an orange in the groin area. (The term "bubonic plague" derives from the Greek word for groin, "bubo.") The patient suffers excruciating pain, and barring effective intervention, almost invariably succumbs to the disease in a matter of three to five days. ${ }^{5}$ If caught early enough, the disease may now be very effectively treated with antibiotics, but this is a very recent therapeutic development.

Plague is a zoonotic disease; that is to say, it is an ailment shared by man and the lower animals. Indeed, plague is primarily a rodent disease, with man acting as a kind of accidental host. The disease is spread from rat to rat and, when rats are not available in sufficient number, from rat to man through the bite of infected rodent fleas. Plague, at least in its bubonic form, is not communicable directly from one human being to another. If, however, the bubonic infections should invade the lungs, another very contagious form of the disease, pneumonic plague, may develop. Pneumonic plague is spread through the coughing of those ill with the disease to persons in close proximity. Though the opposite would seem to be true, the development of pneumonic epidemics out of bubonic outbreaks has been the exception rather than the rule. Bubonic plague has in fact been described as "one of the least infectious of epidemic diseases." In 1900, the distinction between bubonic and pneumonic plague was not understood.

Bubonic plague has probably been endemic in many population centers throughout recorded history, but on several occasions the disease has flared into a pandemic involving large geographical areas of the world and vast numbers of victims. The most notable of those was of course the Black Death of the 14th century. The most recent pandemic of plague originated in southern China in the last decade of the 19th century and by

5. T. Butler, Plague and Other Yersinia Infections 73-79 (1983).

6. L. F. Hirst, The Conquest of Plague: A Study of the Evolution of Epidemiology 29 (1953) ("Hirst, Conquest of Plague"). 
1894 had invaded with force the cities of Canton and Hong Kong. From southern China it spread rapidly to India, Egypt, South Africa, parts of France, Britain, and Australia. By the end of December 1899, a dozen cases had been reported in the Hawaiian islands, concentrated almost exclusively in the Chinese section of Honolulu.

In the waning years of the 19 th century, science made great advances in unraveling the mystery of bubonic plague. The most notable among them was undoubtedly the discovery made independently by Alexander Yersin and Shibasuburo Kitasato in 1894 of the short, ovoid bacillus responsible for causing the disease. There remained, however, a considerable misconception about the ailment's mode of transmission. In 1900, physicians and sanitary authorities around the world were generally convinced that bubonic plague was transmitted from man to man through disease germs emitted by human or rodent plague victims and lurking in the soil, in the air, or in food products. There was an understanding that rats played some role in plague transmission, but there was virtually no understanding of the role played by the rat flea. ${ }^{7}$

\section{THE CHINESE IN CALIFORNIA}

Chinese, almost all from the southeastern province of Kwangtung, had begun to immigrate to California in the early 1850 s to mine for gold. Large numbers were recruited in the late 1860 s to work on the construction of the Central Pacific Railway. In succeeding years many thousands more came and settled throughout the state, working as cooks and domestic servants, in manufacturing industries, in service trades, and in agriculture. ${ }^{8}$ In San Francisco, the state's principal metropolitan center during the 19th century, the Chinese succeeded in carving out an impressive niche for themselves in the local economy, coming by the 1870 s to dominate trades like cigar-making, leather-goods manufacturing, and laundering.

Almost from the beginning of their settlement in California, the Chinese had been the objects of intense racial hostility. This hostility produced a steady stream of Sinophobic legislation that ranged from the petty and mean-spirited to the truly vicious. To rehearse all of it would require a separate paper, but we may mention a few examples: As early as the 1850s California, through a combination of legislation and high court decisions,

7. Id. at 111-15. In 1897 the French researcher P. L. Simond had suggested that the rat flea was the likely plague vector, but his views met little acceptance. An Indian commission established the correctness of Simond's hypothesis beyond any doubt by experiments conducted in Bombay in 1908. Id. at 152-75.

8. For an extremely impressive portrait of the role played by the Chinese in California agriculture during the 19th century, see Sucheng Chan, This Bitter-sweet Soil: The Chinese in Califormia Agriculture, 1860-1910 (1986) ("Chan, This Bitter-sweet Soil"). 
had made it impossible for Chinese to testify against Caucasians in court in either criminal or civil proceedings. In the same decade it passed highly discriminatory tax legislation aimed first at Chinese gold miners and then at other classes of Chinese workers. In succeeding years the state. or its municipalities passed legislation forbidding the employment of Chinese laborers by California business enterprises, requiring the cutting off of the queues of Chinese males held prisoner in the county jail and forbidding Chinese fishermen from fishing in the state's waters. California cities had passed literally dozens of measures throughout the latter decades of the 19th century designed to make it impossible for Chinese laundrymen to carry on their business, and in 1890 the city of San Francisco had reached what may well have been the nadir in legislative Sinophobia when it passed an ordinance that would have required all Chinese inhabitants of the city either to leave San Francisco entirely or to remove themselves to what can only be called an officially demarcated ghetto elsewhere in the city.

These invidious state and municipal laws did not go unchallenged. Individual Chinese or Chinese organizations often repaired to state and federal courts for relief and were remarkably successful in persuading these tribunals to nullify many of these laws on grounds that they violated the principle of equal protection embodied in the Fourteenth Amendment, the Civil Rights Act of 1870 , or the treaty between the United States and China. ${ }^{9}$

The federal legislature, largely neutral on the subject through most of this period, got itself into the business of Sinophobia in 1882 when it passed the first of a series of draconian measures aimed at restricting the flow of Chinese immigration, an immigration that it had itself invited and undergirded with the protection of law. These culminated in the passage in 1892 of the so-called Geary Act, ${ }^{10}$ an extraordinary law that required all Chinese already resident in the United States and entitled both by law and by treaty to remain in the country to obtain certificates affirming their right to stay and to carry them at all times under pain of immediate, summary deportation. As a result of the restrictive federal legislation, the number of Chinese residents in California fell from a high of about seventy-five thousand in 1880 to approximately forty-five thousand in 1900 . Approximately thirteen thousand Chinese were living in San Francisco by

9. On the topic of Chinese resistance to discriminatory legislation, see C. McClain, The Chinese Struggle for Civil Rights in Nineteenth Century America: The First Phase, 1850-1870, 72 Calif. L Rev. 529 (1984), and The Chinese Struggle for Civil Rights in 19thCentury America, 3 Law $\&$ Hist Rev. 349 (1985). See also H. Janisch, The Chinese, the Courts, and the Constitution (Ph.D. diss., 1971).

10. Ch. 60,27 Stat. 25 (1892). 
the end of the century, mainly in the 15-square-block section of the central city known as Chinatown. ${ }^{1 t}$

\section{THE DISCOVERY OF PLAGUE IN CHINATOWN AND THE IMPOSITION OF THE FIRST QUARANTINE}

On the night of March 6,1900, the body of a middle-aged Chinese male with badly swollen lymph nodes in the groin was discovered in the basement of a Chinatown hotel. The physician who first noticed this reported the fact to A. P. O'Brien, health officer of San Francisco, who in turn asked Dr. Wilfred $\mathrm{H}$. Kellogg, bacteriologist of the city Board of Health, to do a microscopic examination of the nodes in question. Kellogg detected bacilli under the microscope that he strongly suspected were those of bubonic plague, a finding he reported immediately to O'Brien and to the president of the Board of Health, John Williamson. That same night, at the insistence of health officer O'Brien, a decision was made to take immediate and rather drastic action. The chief of police was summoned and told that the health authorities wished to impose a total blockade on Chinatown. Thoroughly in agreement with the decision, he dispatched a force of 32 officers to the Chinese quarter with orders first to remove all Caucasians from the affected area, then to cordon it off and thenceforth allow no one but Caucasians to leave it and no one at all to enter it. The orders were quickly carried out, and by the morning of March 7, Chinatown had been effectively sealed off from the rest of the city. ${ }^{12}$

The custom of segregating from the community persons afflicted with diseases thought to be communicable dates back to biblical times and was practiced on a grand scale during the Black Death of the 14th century, when plague sufferers in many cities were strictly confined to their houses. During that century, too, the Republic of Venice introduced the practice of requiring ships arriving from places where epidemics were in progress to wait offshore for several days before disembarking passengers or goods. The practice was adopted by numerous other governments, and the waiting period was eventually extended by many to 40 days. Hence the name "quarantine" (from quarantina, the Italian word for 40). ${ }^{13}$ The first federal quarantine law was passed in $1796,{ }^{14}$ and by the end of the 19 th century

11. The best statistics on the Chinese in the United States are to be found in Chan, This Bitter-sweet Soil.

12. San Francisco Examiner, March 7, 1900, at 4, col. 1 .

13. On the history of quarantine, see G. Rosen, A History of American Public Health 63-69 (1958).

14. Act of May 27, 1796; 1 Stat. at Large 474 , ch. 3. 
all American ports, including San Francisco, ${ }^{15}$ had established quarantine regulations of their own, providing for the inspection of incoming vessels and the quarantining of those suspected of carrying contagiously ill passengers.

The quarantine decided upon by San Francisco health officials the night of March 6,1900, was of a drastically different character, however. Though not unprecedented in the history of public health in the western world, it was highly unusual. It applied not to individual ships or houses but to a whole district of a great city. Moreover, it was adopted in response to the discovery of a single case of plague. From the perspective of modern public health we can see that such a measure could be of virtually no use in preventing the spread of bubonic plague. (As one authority put it in the context of describing earlier efforts to seal borders as a means of keeping bubonic plague at bay, "plague rats know no frontiers."16) Even under medical assumptions accepted at the time, the decision had a deep illogic about it, as would be forcefully pointed out by some later in the health crisis when a similar decision was taken. But the decision becomes quite understandable if one factors in the then-prevailing public health orthodoxy concerning Chinatown and the Chinese.

The Chinese quarter of San Francisco had for years been depicted by local health authorities, often in the most garish terms, as the city's preeminent breeding spot for disease and contagion. ${ }^{17}$ As early as 1870 health officer O'Brien had referred to the Chinese as "moral lepers" in the community whose manner of life was of such a character "as to breed and engender disease wherever they reside." $18 \mathrm{He}$ also expressed the fear that, dwelling as they did in the center of the city, any communicable disease that developed in Chinatown might spread quickly to the entire Caucasian population. ${ }^{19}$ One finds the same sort of intemperate language employed repeatedly in reports issued by San Francisco officials in the last decades of the 19th century. Thus, a special committee of the Board of Supervisors, empaneled in February 1885 to look into health conditions in Chinatown, reported in July of that year: "All great cities have their slums and localities where filth, disease, crime and misery abound; but in the very best aspect which Chinatown can be made to present, it must stand apart, conspicuous and beyond them all in the extreme degree of all these

15. Health and Quarantine Laws for the City and Harbor of San Francisco Relating to the Public Health, San Francisco, 1885.

16. Hirst, Conquest of Plague at 407 (cited in note 6).

17. For an excellent account of the attitude of late 19th-century health authorities toward Chinatown, see J. Trauner, The Chinese as Medical Scapegoats in San Francisco, 1870-1905, Califomia History, 1978, at 70.

18. Health Officer's Report, Board of Supervisors, San Francisco Municipal Reports for the Fiscal Year Ending June 30, 1870, at 233 (hereafter these reports are cited as "San Francisco Municipal Reports, [year]").

19. Id. 
horrible attributes, the rankest outgrowth of human degradation that can be found upon this continent." 20 It was, said the committee "a standing menace to the health of the community." 21 The Health Officer's report for the fiscal year 1889-90 referred to Chinarown, significantly, as "this plague spot," 22 and in 1896 his successor had even gone so far as to call for its wholesale destruction. "The plague spot known as Chinatown, and located in the choicest part of the city, should be entirely abolished," he declared, "and with the necessary force of inspectors at my disposal I would gladly undertake the accomplishment of this event."23

Late 19th-century Chinatown was undoubtedly a congested and in many ways unsanitary place (what immigrant quarter in a large American city was not?), and its condition would have been a legitimate concern to anyone charged with responsibility for the public health. But highly charged and contentious rhetoric of the sort just cited betokens more than a legitimate professional anguish about a public health problem; it reveals the deep-seated Sinophobia that pervaded Caucasian opinion, lay and scientific alike, in late 19th-century California. In any event, the Chinese district having been invested by decades of public health iconography with the character of a discrete and undifferentiated hub of disease, one deserving perhaps even of destruction, it is easy to see why when one case of plague is detected in one house in Chinatown, the first reaction of the authorities is to adopt a draconian measure aimed at the whole district.

The report of the discovery of a suspected case of bubonic plague, no doubt because it was only a single instance, did not provoke any general alarm in the city. As to the measure decided upon by the health authorities, opinion differed. In general it can be said the quarantine decision met with approval, albeit rather tepid, in the Caucasian community. The consensus seemed to be that officials at worst were erring on the side of caution and were hardly to be faulted for that stance given the serious nature of the disease. ${ }^{24}$ There were some notable exceptions to this rule, however. The San Francisco Chronicle, the city's leading Republican daily,

20. Report of the Special Committee on the Condition of the Chinese Quarter, and the Chinese in San Francisco; included in San Francisco Municipal Reports, 1885, at 166.

21. Id. at 162 .

22. San Francisco Municipal Reports, 1890, at 316.

23. San Francisco Municipal Reports, 1896, at 80.

24. See, e.g., San Francisco Examiner, March 7, 1900, at 4, col. 1. The Examiner in doggerel bemoaned the dent the absence of Chinese would put in the housework industry:

Scorn not the humble Chinaman

Throw not his uses down

For, as I live, we miss him when He stays in Chinatown

When happy Yip and Yellow Sin

Quit the domestic scene

We have to do this work ourselves

And damn the quarantine. 
saw the whole incident as little more than an attempt by the health authorities, all Democrats, to secure higher budgetary appropriations for the Board of Health and, it hinted, to line their own pockets. It debunked claims of a plague outbreak and warned of the great harm that idle talk of this sort could cause San Francisco. "No greater calamity can befall a city," the paper editorialized, "than the visitation of a plague. Even the suspicion of one is sufficient to terrify the community, paralyze commerce, turn away strangers, and prevent even the visits of neighbors and friends." 25

Having taken this position at the outset of the health crisis, the Chronicle maintained it unaltered until the very end. The whole thing was in its view (a view reflected in editorials and news reports alike) never more than a concoction of local and/or federal health officials for various purposes.

Reaction in the Chinese community to the quarantine decision was swift and bitter. A leading Chinese language daily, Chung Sai Yat Po, under a headline reading "Blockade Is a Violation of the Law," editorialized: "According to the epidemic prevention laws a yellow flag should be planted in front of an epidemic-afflicted house, or the house should be encircled by tapes to warn people off. But never have we heard of blocking the whole town."26 Merchants were heard to complain about the enormous financial losses they would suffer if cut off from intercourse with the rest of the city. ${ }^{27}$ Crowds quickly gathered in Chinatown and in particular at the offices of the Chinese Consolidated Benevolent Association, known also as the Chinese Six Companies, to murmur their displeasure. ${ }^{28}$

The Six Companies was a coordinating council of associations representing the various districts around Canton from which the Chinese immigrants had come (during most of the 19th century they numbered six, hence the name). It had emerged as an informal body in the early 1860 s and taken on more formal existence in 1882 . It was unquestionably the most important organization in Chinese America in the late 19th century,

Id. March 8, 1900, at 6, col. 4 .

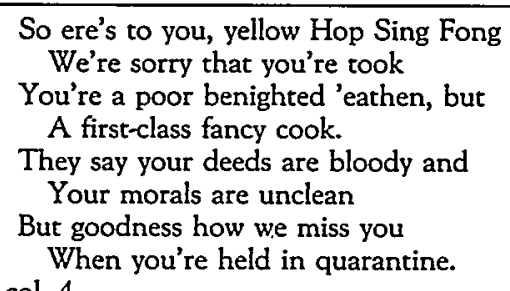

25. San Francisco Chronicle, March 8, 1900, at 6, col. 4.

26. Chung Sai Yat Po, March 8, 1900. I am grateful to Professor Sucheng Chan of the Department of History, University of California, Santa Cruz, for making available to me summaries in English of articles published by this leading Chinese daily during the plague controversy.

27. Sacramento Record-Union, March 8, 1900, at 1, col. 7.

28. Chung Sai Yat Po, March 8, 1900. 
serving as chief intermediary between the Chinese community and the Caucasian establishment and serving from time to time as the often-successful sponsor of test cases challenging the Sinophobic legislation that the state of California and its municipalities were passing with such regularity. It had, for example, sponsored the lawsuit that led to the nullification of the humiliating ordinance requiring the cutting of the queues of Chinese prisoners in the county jail. ${ }^{29}$ One must hasten to add that in 1900 the Six Companies did not enjoy the same unchallenged prominence and power that it did, let us say, in 1880. Nor was its leadership as confident and decisive as it once had been. One can detect a significant erosion in its authority within the Chinese-American community during the last decade of the 19th century that was due to a variety of reasons. It lost considerable credibility by its inability to do anything about the harsh exclusion laws passed by the federal Congress during the 1880 s. Then, too, it was coming to be seen by many as too narrowly tied to the merchant classes; by some as too closely allied with the regime in power in China. It was, nonetheless, still the first organization to which the Chinese, en masse, would turn for assistance when threatened with hostile action by the Caucasian world. ${ }^{30}$

No statement was forthcoming from the Six Companies, but the Chinese consul general was quick to issue one, and he did not mince words: "I think the Chinese have been most unfairly treated, and if something is not done to modify the blockade I will try to obtain relief for the Chinese," he said on March 7. And he added: "It is wrong to close an extensive section like Chinatown simply upon the suspicion that a man might have died of the plague." 31 The next day he clarified what sort of relief he had in mind when he told the local press that, after consultation with counsel, he had decided to apply at once to the federal courts for an injunction to dissolve the blockade of Chinatown. Reflecting what was doubtless the dominant sentiment in the community, he declared: "It is not right to single out the Chinese and treat them in this way." 32 At the same time, he directed the Six Companies to assist in supervising the cleansing and disinfecting of all residences and places of business in Chinatown. ${ }^{33}$

29. Ho Ah Kow v. Nunan, 12 Fed. Cas. 252 (1879). Case no. 6546.

30. The authoritative history of the district associations and of the Six Companies is H. M. Lai, Historical Development of the Chinese Consolidated Benevolent Association, Chinese American History and Perspectives 13-53 (1987); see also S. H. Tsai, China and the Overseas Chinese in the United States, 1868-1911, passim (1983); and M. H. Hunt, The Making of a Special Relationship: The United States and China to 1914, at 68-69 (1983).

31. San Francisco Chronicle, March 8, 1900, at 7, col. 5.

32. San Francisco Chronicle, March 8, 1900, at 1, cols. 2-4.

33. San Francisco Examiner, March 9, 1900, at 9, cols. 1-2. 


\section{THE INVOLVEMENT OF THE FEDERAL HEALTH OFFICIALS}

On the morning of March 7, Board of Health bacteriologist Kellogg took tissue from the suspected plague victim's lymph gland to the federal quarantine station on Angel Island in San Francisco Bay, which had an excellent bacteriological laboratory. ${ }^{34}$ The physician in charge of the federal quarantine station and the man to whom Kellogg submitted his tissue sample was Dr. Joseph J. Kinyoun of the United States Marine Hospital Service, lineal ancestor of the U.S. Public Health Service. Following the standard diagnostic procedure he inoculated several laboratory animals with cells from the tissue sample with a view to observing their reaction.

Joseph J. Kinyoun received his medical degree from Bellevue Hospital Medical College of New York University in 1882 and had then gone on to Europe for further study. While there he worked briefly in the laboratory of the great German microbiologist, Robert Koch. Upon his return to the United States, Kinyoun joined the Marine Hospital Service and was given permission to set up a small bacteriological laboratory, one of the first of its kind in America, on Staten Island, where he applied the new methods he had learned in Europe for the study of infectious diseases. The laboratory, soon to be designated the Hygienic Laboratory, moved to Washington in 1891. Kinyoun remained its director until 1899 , when he was assigned to the post of federal quarantine officer in San Francisco. The laboratory grew in size and scope after Kinyoun left and in 1930 was reorganized as the National Institute of Health. ${ }^{35}$

Kinyoun reported directly to the supervising surgeon general of the Marine Hospital Service, Walter Wyman. Wyman joined the service in 1876 and became its head in 1891 . He was by all accounts a knowledgeable scientist and capable administrator. ${ }^{36} \mathrm{He}$ had taken a special interest in the worldwide plague pandemic and published a monograph on the subject in January 1900.37 Inasmuch as Wyman's views would play a preponderant role in shaping the San Francisco anti-plague campaign, the piece deserves careful analysis.

Medical science in 1900 could look back on its immediate past as a period of extraordinary accomplishment. The era had witnessed, among other things, the invention of anaesthesia, the development of effective techniques of antisepsis, the discovery of the pathogenic organisms respon-

34. Id., March 8, 1900, at 1, cols. 2-4.

35. R. Williams, The United States Public Health Service, 1798-1950, at 249-50 (1950) ("Williams, USPHS"). P. Starr, The Social Transformation of American Medicine 340 (1982).

36. Williams, USPHS at 477-79.

37. Treasury Department Document No. 2165 (Government Printing Office, 1900) (hereafter "Wyman"). The pamphlet was an expanded version of an article by Wyman on the same subject that appeared in the Annual Report of the Marine Hospital Service for Fiscal Year 1897. 
sible for a host of diseases (the germ theory of disease) and quantum improvements in public health technology. ${ }^{38}$ These accomplishments filled some in the medical community with a cocksure optimism verging on hubris that could distort their vision and blind them to some obvious realities. Wyman's monograph breathes this spirit. Bubonic plague, he wrote, "furnishes a striking illustration of the scientific advance of modern medicine. It was not until 1894 that positive knowledge of its true nature became known. Now its cause, method of propagation and the means to prevent its spread are matters of scientific certainty." 39 Plague, like that other great epidemic disease, cholera, had been robbed of its terrors by the advances of modern science, he declared. ${ }^{40}$ Having said this, he went on to echo the regnant and erroneous international consensus concerning plague's mode of transmission. "The methods by which the [plague] bacilli enter the body are three in number," he assured his readers, "by inoculation ... , by respiration, and by introduction into the stomach."41 An individual could, he explained, contract the disease through contact with a wound, an abrasion or infected soil; by inhaling the dust from infected houses or by ingesting infected fluids or food.

Though it was not made explicit, implicit in Wyman's account of plague transmission was the notion that plague germs got into the dust or the air through the sputum, excretions, or exhalations of those infected with the disease. He went on to opine that the disease, like other contagious diseases such as cholera or yellow fever, was favored in its propagation by the presence of filth or other unsanitary conditions in living quarters. ${ }^{42} \mathrm{He}$ also associated himself with the view that Asians, particularly the inhabitants of China and India, might be peculiarly susceptible to the disease because they were fed only on rice and other grains low in protein. ${ }^{43}$ With respect to the long-recognized role of rats as harbingers of plague epidemics, Wyman explained that rats had their snouts about an inch above the floors of houses and were thus more apt than humans to inhale plague-infested dust. ${ }^{44}$ Wyman, like most others, believed that rats could serve as transmitters of plague germs, but through their excreta rather than through the fleas they harbored.

The main measures Wyman recommended for preventing the spread of plague infection in the unlikely event that it should gain a foothold in North America were house-to-house inspection, the thorough cleansing

38. On medical developments during the second half of the 19 th century and on advances in public health, see G. Rosen, A History of American Public Health (1958).

39. Wyman at 10.

40. Id.

41. Id. at 15 .

42. Id. at $15-16$.

43. Id. at $11-13$.

44. Id. at $16-17$. 
and disinfection of infected or suspected houses, the removal of the sick to hospitals and the well to "refuge camps" (he did not elaborate on this measure), and the waging of an active campaign against rats and vermin. Finally, he waxed enthusiastic about a recently developed vaccine called Haffkine's prophylactic and an equally new serum developed by Yersin for, respectively, the prevention and treatment of the disease and strongly recommended that sanitary officials consider their use. ${ }^{45}$

Wyman's confidence in medicine's ability to deal with bubonic plague was apparently not undermined, if he thought of it at all, by the recent British experience in India, where the best efforts of the health authorities, using methods similar to those he advocated, had failed dismally to check the disease's progress. ${ }^{46}$

Surgeon General Wyman became aware almost immediately of the discovery of the suspected plague case both through local newspaper reports and through information supplied by Surgeon James Gassaway, the Marine Hospital Service's medical officer in San Francisco. ${ }^{47}$ Given his special interest in the malady, one can imagine how his curiosity must have been piqued by the development; in fact, he lost no time in plunging into the fray. He first directed his adjutant to offer full assistance to local authorities and then made his own views known as to what course of action

45. Id. at $16-17$ \& $19-24$.

46. On the plague in India see Hirst, Conquest of Plague at 115-20, 416-17 (cited in note 6), and R. Pollitzer, Plague 25-28 (1954). The basic problem with plague was its relative newness. The other great epidemic diseases had been recurring with regularity throughout the modern era, giving an increasingly knowledgeable medical science ample opportunity to observe their course and to experiment with methods of control. The modern plague epidemic was a bare six years old when Wyman wrote. The comparison with cholera was particularly inapposite. As early as 1849, well in advance of Robert Koch's discovery of the cholera bacterium, the London physician, John Snow, by dint of careful observation, had been able accurately to identify the mode of cholera's transmission (through the excreta of cholera victims passed into the water supply), and it was only a matter of time before public health officials were able to devise effective means of preventing the disease's spread. On the subject of cholera see Charles Rosenthal, The Cholera Years 193-97 (1962).

Four components, man himself, a microorganism, an insect vector, and a rodent host, share in the genesis of plague epidemics. The relationship between these components is both subtle and complex and was not fully understood until several decades later, and even then it proved impossible to devise a single strategy of plague control for all countries or even for all areas within the same country. As one of the greatest modern authorities on bubonic plague wrote in the mid-twentieth century: "There is no ready-made stereotyped anti-plague procedure." Hirst, Conquest of Plague at 422. For Wyman, and doubtless for many others, bacteriology's discovery of the plague bacillus made fully clear the way to subdue the disease. In fact, it was but the first step in a long and arduous process.

47. Gassaway to Wyman, March 7, 8, 1890. The original or original copies of this telegram and most subsequent telegraphic correspondence between Marine Hospital Service personnel on the scene and the surgeon general's office in Washington referred to in this article are to be found in National Archives, Record Group 90, U.S. Public Health Service, Central File 1897-1923, \#5608 (hereafter "Nat'l Archives, Record Group 90"). Much of the telegraphic correspondence is also reproduced in Annual Report of the Supervising Surgeon General of the Marine Hospital Service of the United States for the Fiscal Year 1900 (hereafter "1900 Annual Report") at 530ff. The Gassaway telegrams to Wyman of March 7 and 8 are to be found in id. at 530-31. 
ought to be followed. On March 8 he sent a wire urging that, should plague prove to be present in Chinatown, the following recommendations be conveyed post-haste to the local health authorities: that Chinatown be thoroughly disinfected, using sulfur rather than formaldehyde as the disinfecting agent, that anyone known to have been exposed to plague be treated with Yersin's therapeutic serum, and, most significantly, that all other residents of Chinatown be inoculated with Haffkine's prophylactic vaccine. ${ }^{48}$ At the same time, he directed that supplies of the serum and vaccine be sent immediately to San Francisco by express mail. ${ }^{49}$ Wyman's readiness to be of assistance was gratefully acknowledged by local health authorities.

\section{THE END OF THE FIRST QUARANTINE}

Laboratory animals inoculated with tissue containing the plague virus will normally develop symptoms of the disease in fairly rapid order. Therefore, when Kinyoun's animals had not yet developed symptoms by March 9, some began to waiver in their analysis of what was transpiring. Dr. Kellogg, for example, now said that he was not so certain of his original diagnosis. ${ }^{50}$ In the meantime, restlessness and discontent could be seen to be increasing daily in Chinatown. The city's newspapers, the Chronicle in the forefront, were showing signs of skepticism about the board's handling of affairs, and then of course there was the announced threat of Chinese legal action.

Perhaps for all of these reasons the Board of Health, just as suddenly as it had decided to impose the quarantine on Chinatown, decided suddenly on March 9 to end it. Health officer O'Brien told the press: "We raised the blockade because the general clamor had become too great to ignore and we desired to injure no more people than was absolutely necessary." 51 O'Brien noted that the time in which the inoculated laboratory animals might develop the disease had technically not yet expired but thought that, given all the circumstances, the board's rescission of its original decision was not imprudent.

The Chronicle, evidencing little concern for the affected Chinese but much for the reputation of San Francisco, scored the board for its handling of the entire affair. "It has been telegraphed to the ends of the

48. Id. at 531 .

49. On March 14 Gassaway acknowledged to Wyman receipt of one box of "antipest serum." On March 17 he acknowledged receipt of a box of Haffkine's. Nat'l Archives, Record Group 90. On March 8 Gassaway told a reporter that three hundred bottles of "antiseptic and prophylactic serum" had been shipped. San Francisco Examiner, March 8, 1900 , at 1, cols. $2-4$.

50. San Francisco Chronicle, March 10, 1900, at 7, cols. 1-3.

51. Id. 
earth," the paper editorialized, "that San Francisco is an infected city."52 On the other hand, Democratic Mayor James Phelan went out of his way to defend the decision to quarantine and dismissed out of hand Chinese complaints about unfairness: "I desire to say," he declared, "that they are fortunate, with the unclean habits of their coolies and their filthy hovels, to be permitted to remain within the corporate limits of any American city. In an economic sense their presence has been, and is, a great injury to the working classes, and in a sanitary sense, they are a constant menace to the public health." 53

Health officer O'Brien's caveat about the time that still needed to elapse before Kinyoun's laboratory animals could be declared free of the disease proved prophetic, for on March 11 three of the inoculated laboratory animals died, and both pathological and bacteriological examinations by Kinyoun's laboratory established beyond question that the cause of death was bubonic plague. Kinyoun invited members of the Board of Health to visit his Angel Island facility to confirm his diagnosis. ${ }^{54}$ Having satisfied themselves that Kinyoun's diagnosis was correct, the board convened on the night of March 11 and again the next day to determine what measures ought to be taken. For a brief moment it toyed with the idea of reimposing a quarantine on Chinatown, but when the board was informed that the mere mention of the possibility of a new blockade was causing many Chinese to flee the quarter ${ }^{55}$ it relented and decided on a less drastic course of action. It called for a force of volunteers to undertake a houseto-house inspection of all of Chinatown, with a view to thoroughly cleansing and disinfecting the area and isolating any additional suspected plague cases. ${ }^{56}$

It is significant to note that lawyers representing both the Chinese Six Companies and the Chinese Consulate were present at the Board of Health meetings. They pledged their cooperation. (It will be remembered that the Consul had already asked the Six Companies to supervise a general clean-up of the area.) The attorney for the Six Companies, former Judge D. J. Murphy, said that the organization could supply people to assist in the inspection of Chinatown. "The only thing I ask," he added, "is that you treat those people kindly." 57 John Bennett, the attorney representing the consul general, declared the consulate's equal willingness to cooperate and noted that it had already posted notices requesting the Chi-

52. Id. at 6 , col. 2 .

53. Id. at 7, cols. 2-3.

54. San Francisco Examiner, March 12, 1900, at 2, cols. 1-3.

55. San Francisco Chronicle, March 12, 1900, at 10, col. 4.

56. Accounts of board meetings and actions taken from San Francisco Chronicle, March 13, 1900, at 10, col. 4, \& 12, col. 5; San Francisco Examiner, March 13, 1900, at 7, cols. 3-5.

57. San Francisco Examiner, March 13, 1900, at 7, cols. 3-5. 
nese to summon white physicians in cases of severe illness. ${ }^{58}$ The next day, as a token of their good faith, the Six Companies and the Chinese consulate posted joint proclamations throughout Chinatown urging all inhabitants to cooperate with Board of Health officials in their efforts. ${ }^{59}$

The board-ordered inspection and disinfection of Chinatown were dismissed by the San Francisco Chronicle as further proof of the incompetency of the city's governors. It continued to insist that there was neither plague nor danger of plague in San Francisco and that to say otherwise was to do irreparable harm to the city's commerce. ${ }^{60}$ Other papers echoed the same theme, ${ }^{61}$ but the San Francisco Examiner roundly rebuked its fellow journals for criticizing the board and commended it for its decision. ${ }^{62}$ The Sacramento daily Record-Union (papers in the state's interior were following now with lively interest the events transpiring in San Francisco) enthusiastically applauded them and urged Sacramento's city fathers to order the cleansing of the capital's own Chinese quarter "from sewer to garrett" and of every Chinese and Japanese laundry in the city as well. ${ }^{63}$ It saw the board's measures as fully warranted precautions from a sanitary standpoint and even predicted that they would have salutary economic effects on California's white population: "All this wage question in competition with Mongolian labor depends upon the order of living. Because the Chinese can herd together in small quarters, live upon a few cents worth of food a day, divide rentals to invisibility, and exist where white labor would starve, is the main reason why white cannot successfully compete with Chinese labor."64

Implementation of the Board of Health's decrees got underway slowly but picked up pace as the month wore on. The specific actions undertaken by city police, health officials, and those who volunteered to assist them included: a house-to-house inspection of Chinatown residences, the fumigation of dwellings and sewers with sulfur dioxide, the washing of walls and ceilings with a solution of lye or bichloride of mercury, and the spreading of chloride of lime on the district's streets. In addition, a great deal of dry refuse was removed from houses and burned. The Chinese were reported to be cooperating fully with the authorities. ${ }^{65}$ These measures were aimed primarily at killing plague germs, which, as noted above, were believed to be lurking about in the soil, on the interior surfaces of

58. Id.

59. San Francisco Chronicle, March 13, 1900, at 12, col. 5.

60. Id.

61. See, e.g., San Francisco Call, March 14, 1900, at 6, col. 3; San Francisco Bulletin, March 15, 1900, pr 6, col. 2.

62. San Francisco Examiner, March 14, 1900, at 6, col. 1.

63. Sacramento Record-Union, March 23, 1900, at 2, col. 2.

64. Id., March 17, at 2, col. 2.

65. San Francisco Examiner, March 23, 1900, at 7, col. 3. 
rooms, in the possessions of the sick, and in the air. ${ }^{66}$ They were similar to the sorts of measures public health authorities would have undertaken to combat an epidemic of smallpox, scarlet fever, diphtheria, or other classic infectious disease and almost duplicated the actions taken by the Municipal Council of Bombay three years earlier when plague broke out in that city. ${ }^{67}$ In retrospect, we can see that they would have been of little or no use in combatting an incipient outbreak of bubonic plague. ${ }^{68}$

\section{THE DISCOVERY OF NEW CASES AND THE DECISION TO INOCULATE THE CHINESE AND JAPANESE}

An alarming product of the inspection of Chinatown was the discovery by the middle of the month of three more suspected plague cases. This provoked an angry response from Board of Health President Williamson. He declared his belief that the Chinese quarter of the city was "infested" with the disease and that the Chinese were concealing cases. ${ }^{69} \mathrm{He}$ pledged that every house in Chinatown would be searched and that the whole area would be, as he put it, "drenched" with disinfectants. ${ }^{70} \mathrm{He}$ wrote to the president of the state Board of Health, W. P. Matthews, requesting him to direct health authorities in the state's interior to keep a close watch on Chinese settlements in their vicinity and to be especially vigilant about Chinese who might recently have arrived from San Francisco. ${ }^{11}$

66. From reports in the San Francisco Examiner and Sacramento Record-Union, midMarch 1900. See also V. Link, A History of Plague in the United States of America 3 (1955).

67. Hirst, Conquest of Plague 117 (cited in note 6).

68. Even at the time the inefficiency of such measures was recognized by some. In 1898 Hankin, Simond, and other bacteriologists had pointed out that plague bacteria survived outside the body only for the shortest time, at least in tropical climates. See id. In Australia, where a true plague epidemic was raging contemporaneous with the San Francisco events, government authorities, thanks in part to the discovery by Sydney doctors of a plague bacillus in the stomachs of rat fleas, issued a circular warning plague-infested towns that cleansing and disinfecting could not stamp out the disease. They urged instead that measures be aimed at destroying rats. This was reported in the San Francisco Examiner, May 18,1900 , at 3 , col. 7 .

69. A view shared by Health Officer O'Brien. Throughout the epidemic Caucasian officials often expressed the belief that the leaders of the Chinese community were engaged in a conspiracy to conceal plague cases. To be sure the Chinese were very skittish about dealing with Caucasian officials, and there may have been instances where individual Chinese sought to conceal cases of sickness. But there is no credible evidence of a conspiracy among the leadership.

70. Sacramento Record-Union, March 23, 1900, at 6, cols. 1-3. There are echoes here again of Bombay; Hirst, in his account of the hygienic measures employed in that city to combat the plague, writes: "Never in the history of hygiene have disinfectant solutions been employed in such profusion .... [One epidemiologist] had to put up an umbrella before entering some plague houses in order to protect himself against the deluge of carbolic acid solution descending from the upper stories into which the disinfectant was being pumped by a fire engine." Hirst, Conquest of Plague 117 (cited in note 6).

71. Sacramento Record-Union, March 24, 1900, at 3, col. 1. 
The discovery of the three new suspected plague cases was reported by the Associated Press wire service, and its dispatch appeared in several East Coast newspapers. ${ }^{72}$ The outcry in certain quarters of the city about the damage that these reports were doing to San Francisco prompted Mayor Phelan to send an urgent telegram on March 26 to the mayors of 50 eastern cities: "Eastern newspapers just received refer to a sporadic case [sic] of bubonic plague in San Francisco. The Board of Health reported Chinatown has been inspected and disinfected. No other case has appeared. All persons now freely visit the district as usual. On account of the vigilance and efficiency of our health department and Federal quarantine there is no further danger. Please give this to your local press as an act of justice to San Francisco." 73

Phelan's assertion that only one case of plague had been detected in Chinatown was technically correct because the diagnosis of the other three cases had yet to be confirmed. But in fact the local and federal health authorities had little doubt about them as Williamson's statement clearly showed. One catches in the anguished tone of Phelan's telegram something of the cold fear that must have seized him at the thought of what might happen to the city's trade and commerce should other parts of the country become convinced that San Francisco was in the grips of a fullblown epidemic of bubonic plague. It was a fear shared by many of the city's political and business leaders, ${ }^{24}$ and Phelan doubtless would have come under pressure to do more to allay concerns outside had not events, or more accurately, the lack of events come to his rescue. Days and then weeks passed without any new reports of plague in Chinatown, and by mid-April the subject had quite faded from the public mind. The Board of Health's cleansing and disinfecting efforts continued and were even extended to part of the city's Italian district, which adjoined Chinatown. On April 24 yet another suspicious death occurred in Chinatown, but the news caused little stir. One has the sense of general, if slightly uneasy, consensus among health officials that things were now under control and that the worst of the episode was over.

This air of confidence, if it can be so described, was rudely shattered several weeks later when in the short space of three days, May 11,12, and 13, four deaths occurred in Chinatown that seemed in all probability due to plague. While local authorities pondered what to do about this new and untoward turn of events, Surgeon General Wyman, who had been kept abreast of developments by his officers on the scene, Surgeons Gassa-

72. See San Francisco Chronicle, March 24, 1900, at 9, col. 6.

73. Id., March 27, 1900, at 6, col. 2.

74. Several weeks later, in mid-April, the Manufacturers and Producers Association of San Francisco adopted a resolution urging the local press to be cautious about its teports on the plague situation in San Francisco. 
way and Kinyoun, ${ }^{75}$ decided that the time had come for the federal government to interpose itself more forcefully into the events that were transpiring. Indeed the time had come for the Marine Hospital Service to seize the initiative and assume control of the plague-control campaign. On May 15 he dispatched a telegram to Kinyoun. It is worth quoting in full:

Chinese Minister has agreed to wire Consul General, San Francisco, to use his influence to have the Chinese comply cheerfully with necessary measures and consult with you as representative of the United States Government. Confer with Consul General. Have about twenty thousand Haffkine on hand; will be sent to-morrow. If Gassaway has any get it. Suggest advisability of following measures: One man in supreme charge; subordinates in charge of division. Cordon of suspected area; guard ferries and R.R. stations with reference to Chinese only; house to house inspection with Haffkine inoculation; Chinatown to be restricted; pest house in Chinatown, using some substantial building; suspects from plague houses to be removed to a suspect house in Chinatown, if you deem necessary to Angel Island; a disinfecting corpse; destruction of rats; inspection of R.R. and outside territory. ${ }^{76}$

If still a trifle vague on some details, the telegram's message was in its main point quite clear. As the chief means of combatting the plague outbreak Wyman had decided on the mass inoculation of 'San Francisco's Chinese population with Haffkine's prophylactic vaccine. ${ }^{27}$ The plan would have an element of coercion to it.

\section{HAFFKINE'S PROPHYLACTIC VACCINE}

The vaccine with which federal and local health authorities were proposing to inoculate the Chinese inhabitants of San Francisco consisted of a killed broth culture of the plague bacillus. It had been introduced to the world only three years earlier, in 1897 , by Waldemar Haffkine, a renowned Swiss bacteriologist who had been trained in Paris at the Pasteur Institute. Haffkine was in India when the plague epidemic broke out in that country and was commissioned by the Indian Home Department to conduct research on methods of dealing with the disease. Within a few months he

75. See series of telegrams from Gassaway to Wyman in Nat'l Archives, Record Group 90, and 1900 Annual Report at 537 (both cited in note 47).

76. 1900 Annual Report at 538. A copy of the telegram is also to be found in the documents submitted by the defendants in the case file of Wong Wai v. Williamson, Civil Case No. 12,937, Nat'l Archives, San Francisco Branch, Record Group 21 (hereafter "Wong Wai case file").

77. I have been unable to find any documents throwing light on Wyman's discussions with the Chinese minister or on what they agreed to. 
announced that he had available and ready for use an effective vaccine against the plague. In short order something resembling a controlled experiment with the vaccine was attempted in a Bombay prison (Bombay was one of the worst affected Indian cities), where half of the inmates volunteered to be inoculated. The results seemed encouraging to Haffkine and his fellow researchers, and a laboratory was soon founded for the mass production of the vaccine. Needless to say, Haffkine's announcement aroused enormous interest around the world, especially in those countries where plague had taken root, and thousands of doses were sent out from Haffkine's laboratory in the next few years. ${ }^{78}$

The vaccine was highly toxic, and its administration was frequently accompanied by localized pain and swelling, erythema, headache, and high fever. Reactions were occasionally quite severe and could render an individual prostrate for many days. There were occasionally even reports of death. (In a Punjab village, for example, 14 people died after they were inoculated with a contaminated batch of the vaccine.) $)^{79}$ Under the best of circumstances, an inoculated person would be incapacitated for a day or two. For these reasons it proved difficult, not only in those early years but even later when improved versions of the vaccine were developed, to persuade people to submit to inoculation. (Adding to the difficulty was the fact that inoculated individuals occasionally still caught the disease. $)^{80}$ Nonetheless, in the period between the development of the vaccine and the close of the 19th century many thousands did agree to be inoculated, most of them in those parts of India where plague seemed to be raging out of control. ${ }^{81}$

In few places was enthusiasm for Haffkine's discovery greater than among officials of the American Marine Hospital Service, and the United States was one of the first countries to set up its own manufacturing facility-in the Service's Hygienic Laboratory. It will be remembered that Surgeon General Wyman had waxed eloquent both about the vaccine and about the therapeutic serum that the French bacteriologist Alexandre Yersin had recently developed. Indeed, he had written in that monograph: "it will in the future, be just as rational and scientific to practice preven-

78. J. Taylor, Haffkine's Plague Vaccine, The Indian Medical Research Memoirs, Memoir no. 27, 1933, at 3-7. For an account of Haffkine's life and work see S. Waksman, The Brilliant and Tragic Life of W. M. W. Haffkine, Bacteriologist (1964).

79. See Maj. A. H. Moorhead, Plague in India, 22 Military Surgeon, no. 3 (1980); reprinted in F. M. Todd, Eradicating the Plague from San Francisco 279 (report of Citizens Health Committee, 1909); see also J. W. Cell, Anglo-Indian Medical Theory and the Origins of Segregation in West Africa, 91 Am. Hist. Rev. 307, 327 (1986).

80. See K. F. Meyer et al., Plague Immunization: Past and Present Trends, 129 J. Infectious Diseases 513 (1974).

81. On India see J. K. Codon, The Bombay Plague 1-50 (1900). Several hundreds of persons living in the Australian state of Victoria availed themselves of the opportunity to be inoculated with the vaccine in early 1900. See R. J. Bull, The Practical Application of Haffkine's Plague Prophylactic in Victoria, 5 Intercolonial Med. J. Australia 148-50 (1900). 
tive inoculation against the plague as it is now customary to vaccinate those exposed to the infection of small pox with a view to preventing the spread of the disease." 82 When in late 1899 and early 1900, the epidemic first touched American possessions, to wit, the Philippines and the Hawaiian islands, and seemed to threaten the American mainland, interest in the vaccine quickened. The correspondence files of the Marine Hospital Service for this period are full of reports of both the Haffkine vaccine and the Yersin serum being shipped to various destinations in the continental United States and in outlying U.S. possessions. Indeed, in June of 1900 Surgeon General Wyman ordered supplies of the vaccine sent to all federal quarantine officers. ${ }^{83}$

The first occasion for the use of Haffkine's vaccine on any significant number of people on American soil occurred in Honolulu. In February and March of 1900, during the final phase of the plague outbreak in that city, a fairly large quantity of the prophylactic was shipped to D. A. Carmichael, the Marine Hospital Service's medical officer in command there. Carmichael wished to persuade the local health authorities to require all of those who had been removed to detention camps from Honolulu's Chinatown to be inoculated with the vaccine, but the local health board did not see fit to adopt this measure. Instead, the board adopted an order requiring vaccination only for those who wished to leave Oahu for other points in the islands. Otherwise, the vaccine was made available on a voluntary basis to any who chose to use it. Among those who did volunteer were local health officials, the crews of some ships that were preparing to sail, and members of both the American consulate in Honolulu and the Marine Hospital Service station. There does not seem to have been a rush to be inoculated. 84

It is almost impossible to assess today with any degree of certainty how effective Haffkine's early solution might have been as plague preventive. Some data suggest it was efficacious, although the statistical evidence that most impressed the world, namely, that offered by Indian authorities, is now viewed with some skepticism. ${ }^{85}$ Plague immunology has from the

82. Wyman at 23 (cited in note 37 ).

83. See numerous letters and telegrams in Nat'l Archives, Record Group 90 (cited in note 47). Wyman's June directive can be found there too. It will be recalled that one of Wyman's first reactions to the discovery of plague in San Francisco was the dispatch of quantities of Haffkine's vaccine and Yersin's serum. See text accompanying notes 47-49 supra.

84. See the several letters from Carmichael to Wyman in February, March, and April 1900 in Nat'l Archives, Record Group 90. The leading 20th-century authority on plague vaccines, K. F. Meyer, declared that the vaccine used in Hawaii was so toxic and reactions to it so severe that its use had to be discontinued. Meyer et al., 129 J. Infectious Diseases at 513 (cited in note 80 ).

85. Hirst thinks that the vaccine probably was fairly effective. See Hirst, Conquest of Plague 417 (cited in note 6). Butler is much more skeptical. T. Butler, Plague and Other Yersinia Infections 199 (1983). The leading modern researcher on plague immunology was K. 
beginning been a controversial study. Indeed, as recently as 1983 a leading authority on plague, notwithstanding decades of improvement in the technology of producing Haffkine's vaccine, of experimentation with laboratory animals, and of observation of human subjects, could write: "The efficacy of killed vaccines in preventing human plague has been claimed but never proven in a randomized field trial." 86 One thing can be said with certainty: In May of 1900 Haffkine's prophylactic was, and was understood by most scientific contemporaries to be, still an experimental drug.

\section{EVENTS IMMEDIATELY FOLLOWING THE WYMAN TELEGRAM OF MAY 15}

For what transpired in the immediate wake of Surgeon General Wyman's May 15 telegram we must rely entirely upon the recollections of Surgeon Kinyoun, contained in a letter that he wrote to his chief on June 11.87 According to this letter, immediately upon the receipt of the telegram (whether on May 15 or 16 is not clear) he met with the Chinese consul general, Ho Yow, and John Bennett, attorney for the Chinese Six Companies. At this meeting, he relates, he fully discussed the plague situation with them and secured their agreement that "the most reasonable solution of the question was to advise all the Chinese residents living in the infected area" to submit to inoculation with the Haffkine vaccine. ${ }^{88}$ On the same day, he further relates, he attended a conference with representatives of the San Francisco Merchants Association and the local board of health, at which conference Bennett also was present. According to Kinyoun, it was the general impression among those present at the meeting "that the Chinese and Japanese [my emphasis] would gladly avail themselves of inoculation in order to obviate the necessity of enforcing more

F. Meyer of the University of California. Some sense of the historical controversy concerning the efficacy of plague vaccines can be had from reading Meyer et al., $129 \mathrm{~J}$. Infectious Diseases, and Meyer, Effectiveness of Live or Killed Plague Vaccines in Man, 42 Bull. World Health Organization 653 (1970). See also 7 Inf. Dis. II Gram-Negative Bacilli 31, Scientific American Medicine, March 1987, characterizing the modern vaccine's effectiveness as "difficult to assess."

86. Butler, Plague and Other Yersinia Infections 199 (1983). In 1906 a federal health official who had conducted extensive experiments in the Philippines with both live and killed vaccines wrote: "I . . . concluded from animal experiments, as well as from the fact that a number of persons who had received several injections of Haffkine's prophylactic later sickened and died with plague that the killed pest organism constituted for man a far from satisfactory protective against the disease." Richard Strong, Vaccination Against Plague, 1 Philippine J. Sci. 181, 186 (1906). Since the discovery of effective antibiotics, immunization has played an increasingly insignificant role in combatting bubonic plague outbreaks.

87. All details of Kinyoun's narrative are taken from his letter to Wyman of June 11 , 1900, in 1900 Annual Report at 558-61.

88. Id at 559 . 
severe measures." He records that he expressed skepticism at this prediction, suggesting that compulsory inoculation, while it could not then be considered, "was the only recourse." 89

The following day (at Bennett's suggestion, according to Kinyoun) yet another meeting was held, this one involving, in addition to the consul general, the board of health, and representatives of the merchants association, a large number of Chinese from the Six Companies. Kinyoun was not present at this meeting, but his deputy surgeon Gassaway was. The meeting's main upshot was a reaffirmation by the Chinese leaders of their commitment to recommend to the Chinese population that it submit to inoculation. "It was understood by the board as well as others that there would be no opposition by the Chinese to accepting vaccination," Kinyoun writes. .90

One should read Kinyoun's narrative with some measure of reserve. It was written almost a month after the events, at a time when federal health policies had suffered several reverses, and when Kinyoun had every reason to paint his earlier actions in as rosy a hue as possible. The letter has a strong defensive air about it. That said, on the bare facts it is probably correct. One may well believe that the Chinese leaders promised Kinyoun that they would recommend inoculation. One may be excused from believing, however, that they did so entirely of their own accord, having become persuaded, as it were, by Caucasian merchants and health authorities that this was the most prudent course of action from a community health standpoint. These decisions were taken in what must have been a pressure-cooker atmosphere. Furthermore, Kinyoun's task was not to win Chinese approval for a plan under deliberation, but to secure their endorsement of a course of action already decided upon. And he had a powerful bargaining chip on his side-the threat, as he put it, of "more severe measures." 91

On May 18 Wyman sent a second telegram to Kinyoun, expanding further on the steps that were to be taken to implement the proposed inoculation scheme:

In event bumpkin [i.e. plague] becomes officially proclaimed see J. C.

89. Id.

90. Id, Gassaway's own telegraphic report of the meeting to Wyman reads: "Chinese are to be inoculated by Burlesque [Marine Hospital Service telegrams often employed code when speaking of the plague outbreak. "Burlesque" meant the San Francisco Board of Health]. Physicians will present themselves at ten o'clock on morning twentieth for that purpose. Each will be furnished certificate when inoculared. Conference very friendly. Newspapers keeping affairs quiet and no excitement among citizens." Nat'l Archives, Record Group 90 (cited in note 47).

91. It is not clear from Kinyoun's account whether the Chinese leaders fully understood the extent of what Wyman was contemplating, that is to say not just a massive, albeit voluntary, inoculation campaign, but a campaign that already had elements of coercion built into it. 
Stubbs third Vice President Southern Pacific or J. Kruttschmitt General Manager and request refusal sale of tickets to Chinese or Japanese [my emphasis] without accompanying certificate from Marine Hospital officer. ${ }^{92}$

The May 15 dispatch had referred to the guarding of ferries and railroad stations "with reference to Chinese only." What Wyman had in mind now became much clearer. Through the cooperation of the transport companies the Chinese were going to be presented with the alternatives of being inoculated or having their freedom of movement restricted. Interestingly, for the first time, Wyman's concern was now extended beyond the Chinese to include San Francisco's small but growing Japanese population as well. The same evening the San Francisco Board of Health met in extraordinary session to consider the new federal proposals. Little time was lost in debating them, and in short order they were unanimously endorsed, although the resolution of endorsement took a curiously general form. It said simply that it was the board's sense that bubonic plague existed in the city and county of San Francisco and that the steps already taken for the prevention of its spread should be continued "together with such additional measures as may be required." 93

On May 19 Kinyoun informed the railroads that they should refuse passage out of San Francisco any Chinese or Japanese who did not possess a certificate of inoculation. ${ }^{94}$ At the same time, he ordered inspectors posted at common points of exist from the city and at crossing points between California and the adjacent states of Arizona, Nevada, and Ore-

92. A handwritten copy of the telegram is to be found in the case file for Wong Wai v. Williamson, Civil Case No. 12937, National Archives, San Francisco Branch (hereafter "Wong Wai case file"). It is not reproduced in the 1900 Annual Report.

93. Copy of the resolution in the Wong Wai case file. Id.

94. Letrer Kinyoun to Wyman, May 19, 1900, 1900 Annual Report at 540, and Sacramento Daily Record-Union, May 20,1900, at 1, col. 4. The extension of the inoculation requirement to Japanese as well as Chinese seeking to leave the city caused a major row with the Japanese government's representatives in the United States. In correspondence both with Board of Health President John Williamson and with Surgeon Kinyoun, Count Mutsu, the Consul-General in San Francisco, protested that the requirement was racially discriminatory, unjustified under the circumstances, and finally not authorized by law. "My . . . object," Mutsu wrote to Williamson on May 21, "is to urgently protest against the treatment to which my countrymen have been singled out and subjected, the same appearing to me as an unjust discrimination not warranted by present conditions in the city of San Francisco." And on May 22 the Japanese charge d'affaires in Washington complained to Secretary of State John Hay that the surgeon general's order was "not general in character but is only applicable to two nationalities. To that extent, therefore, it discriminates against those nationalities and in favor of the people of other nationalities in San Francisco." This he thought violated the equal treatment provision of the treaty between the United States and Japan. Copies of the relevant correspondence are in National Archives, Record Group 90, \#5608. This correspondence is especially interesting in view of the fact that certain Caucasian commentators claimed that the greater willingness of Japanese to submit to inoculation demonstrated the superiority of that nationality over the backward Chinese. See Sacramento Record-Union, May 20, 1900, at 1, col. 4; and May 24, 1900, at 8, col. 1. 
gon. ${ }^{95}$ Two days later the government in Washington sought to legally undergird these decisions. The secretary of the treasury, at Wyman's insistence, promulgated a regulation authorizing the surgeon general, while plague existed in the United States, "to forbid the sale or donation of transportation by common carrier to Asiatics or other races particularly liable to the disease." 96 The regulation was said to be based on a federal statute passed in 1890.97

\section{REACTION IN THE CHINESE COMMUNITY}

Rumor that the health authorities were planning some kind of mass inoculation had begun to percolate through Chinatown as early as May 17, and in the words of the Chinese daily Chung Sai Yat Po, immediately "plunged the town into disorder."98 A large crowd of very agitated people gathered at the offices of the Chinese Six Companies, shouting their determination not to submit to inoculation. The merchant leaders of the association seemed at a loss as to what to do to calm the crowd until one of them took the floor and promised that a lawyer would be retained and

95. Minutes of state Board of Health, in Wong Wai case file (cited in note 76).

96. The full text of the regulation promulgated by Secretary of the Treasury L. J. Gage and distributed as Department Circular $93(1900)$ to all medical officers of the Marine Hospital Service and to state and local health authorities read as follows:

In accordance with the provisions of the act of March 27, 1890, the following regulations, additional to existing Interstate Quarantine Regulations, are hereby promulgated to prevent the introduction of plague into any one State or Territory or the District of

Columbia, from another State or Territory or the District of Columbia:

1. During the existence of plague at any point in the United States the SurgeonGeneral of the Marine Hospital Service is authorized to forbid the sale or donation of transportation by common carrier to Asiatics or other races particularly liable to the disease. [emphasis added]

2. No common carrier shall accept for transportation any person suffering with plague or any article infected therewith, nor shall common carriers accept for transportation any class of persons who may be designated by the Surgeon-General of the Marine Hospital Service as being likely to convey the risk of plague contagion to other communities, and said common carriers shall be subject to inspection.

3. The body of any person who has died of plague shall not be transported except in an hermetically sealed coffin and by consent of the local health office, in addition to the local representative of the Marine Hospital Service. Wherever possible, such bodies should be cremated.

The Marine Hospital Service circular is dated May 22, 1900, but it appears that the Treasury regulation was actually issued on May 21.

97. Act of March 27, 1890, ch. 51, 26 U.S. Statutes at Large 31 (1889-91). The statute authorized the president, whenever it should be made to appear to his satisfaction that cholera, yellow-fever, smallpox or plague existed and threatened to spread across state or territorial lines, to cause the secretary of the treasury to promulgate such rules and regulations as would, in his judgment be necessary to stop the spread.

98. According to Kinyoun the entire trouble was due to white physicians who went about the Chinese quarter spreading false rumors about the vaccine. Letter of Kinyoun to Wyman, at 559. 
some sort of legal action brought against the health officials. A reporter for Chung Sai Yat Po, apparently unable to locate the Chinese consul, took it upon himself to find the Chinese consulate's attorney, John Bennett, in order to find out exactly what was going on. Bennett sought to allay popular fears by assuring the reporter that inoculation would cause minor, temporary discomfort and would do no long-lasting harm. The reporter told Bennett that the Chinese would never submit to forced inoculation and wondered aloud why Consul Ho "was so lazy as not to lodge a protest." Bennett sought to defend Ho. The consul, he said, had been very energetic in representing Chinese interests, and it was only because of these efforts and those of some sympathetic American merchants that more draconian measures, a blockade, or even worse, the razing of the Chinese quarter, were thwarted. ${ }^{99}$

As word spread to more people in the community, fear, at times bordering on panic, and resentment increased. The next day large groups of people could be found milling about in the streets of Chinatown murmuring anxiously about what was in the offing. An even larger and more unruly crowd gathered at the Six Companies offices. Many could not squeeze into the association's premises and hovered around outside. Someone in the assembly pointed out (correctly) that what was being proposed was quite different from smallpox immunization, that persons inoculated with the plague vaccine would run a fever for several days, and that inoculation might be devastating to a frail person. Someone else proposed that all business establishments in Chinatown be shut down in protest, a proposal that met with great approval from those assembled. ${ }^{100}$ Events were beginning to press in on the leaders of the Chinese community. Neither Consul Ho nor his counterparts in the Six Companies foresaw how deep or intense the community's opposition would be to the idea of inoculation with the plague prophylactic.

On May 18 the Chinese Six Companies and Consul General Ho sent an urgent joint cable to the Chinese minister in Washington.

Authorities insist inoculation, even by force, all Chinese object, would rather go back to China than subject. They say there is no plague at all. Please use your influence at once have authorities have officers here to facilitate matters as they intend to commence at once. If they inoculate by force there might be trouble and bloodshed and may lead to serious complications. ${ }^{101}$

99. What We Should Do About Inoculation, Chung Sai Yat Po, May 18, 1900.

100. The Background of Vaccination, Chung Sai Yat Po, May 19, 1900.

101. Copy of the cable to be found in Nar'l Archives, Record Group 90. Consul Ho sent the following separate cable to his minister: "Health officials want the Chinese to be inoculated to guard against the plague. Chinese generally unwilling. Great consternation. They say there is no plague and want to fight it out. Did all I can." Id. The Chinese 
They also dispatched Bennett and two other lawyers to inform the board of Chinese resistance to forcible immunization, but they returned to the offices of the Six Companies late in the evening of the 18th emptyhanded. The authorities could not be deflected from their inoculation plans, which were set to commence the next day. The Chinese could refuse to be inoculated, but if they did they would not be permitted to leave the limits of the city and county of San Francisco. Having taken these actions, the Six Companies informed the Chinese community that their lawyers would continue to consult with the health authorities and that the community should await the result of these consultations and of the negotiations that the Chinese minister was entering on with federal officials in Washington. In the meantime, they urged the Chinese "not to argue with the health officers" who would be coming to administer inoculation. ${ }^{102}$

Early in the morning of May 19, 1900 a sizable force of physicians and municipal health workers, armed with hypodermic syringes and ample supplies of Haffkine's prophylactic, descended upon Chinatown to administer the inoculation to those who would have it. Not surprisingly, they found very few takers. Caucasian journalists who visited Chinatown reported that opposition to inoculation was almost universal. Large numbers of businesses shut down to signify opposition to the board's actions. Knots of Chinese gathered on street corners to denounce it. Many were frantically trying to leave Chinatown. Chinese merchants, interviewed by the press, threatened to go to court to prevent forcible inoculation. Coming quickly to the crux of the matter, they pointed out that the vaccine was "experimental," and, they declared, "they wished to protect their persons." 103 By the end of the first day only a handful of Chinese had agreed to be inoculated.

Nothing materially changed in the next days. No mass of Chinese presented themselves for inoculation on the morning of May 20, as had been envisioned by the plan discussed a few days earlier. Someone from the health authorities conceived the idea that if health personnel allowed

minister passed these on to Surgeon General Wyman with a request that he wire his officers in San Francisco to "use more tact and discretion so as to avoid complications." Id.

102. Supra note 77.

103. See accounts of the first day's events in Sacramento Record-Union, May 20,1900, at 1, col. 4. Undoubtedly, another factor, besides apprehension about the vaccine's experimental character, contributing to Chinese reluctance to undergo inoculation was the lack, to their minds, of any apparent pressing necessity for such an extreme measure. To the lay mind, the Chinese included, no doubt, plague was a disease that spread like wildfire and that if it existed in the city of San Francisco should be affecting dozens of victims daily. But what the health authorities were talking about were a relative handful of cases spread over several months. And indeed at the time the inoculation campaign began there were no existing cases under treatment. This made it difficult for the Chinese and many Caucasians as well, to believe that plague existed at all, notwithstanding the very strong bacteriological evidence in the individual cases mentioned. On May 23, for example, Chung Sai Yat Po editorialized that it was "ridiculously impossible" to believe that so few people would have died over such a long period of time if a true plague epidemic existed. 
themselves to be inoculated publicly, the Chinese would see they had nothing to fear from the vaccine. The example had no such effect; if anything, opposition stiffened as each day passed. The western press rumored that tong gangsters were threatening anyone who submitted to inoculation. ${ }^{104}$ Despite the pleas from the Six Companies and the consul general that they reopen, most businesses continued to remain closed, and posters appeared threatening to take the life of any merchant who dared reopen. ${ }^{105}$ A large and unruly crowd of people twice surrounded the residence of Consul Ho on May 21, demanding that he take forceful steps to prevent compulsory inoculation, and the police had to be summoned to disperse them. ${ }^{106}$ Matters were becoming dicey indeed, and actions taken by Caucasian officials did little to ease tensions. A notice posted by the board of health, for example, sought to assuage concerns by assuring the Chinese population that the government had spared no expense in preparing the medicine that was being used for vaccination and that the Chinese could be inoculated by their own doctors if they so chose. The notices added that it would be self-defeating for the Chinese to refuse vaccination and that if they balked, harsher measures would be considered. ${ }^{107}$

\section{THE CHINESE SEEK THE ASSISTANCE OF THE COURTS}

Notwithstanding the general suspicion of the vaccine that prevailed in the community, a small number of Chinese had agreed to be inoculated in the first days of the campaign. One need not look far for reasons. Many Chinese either worked or had business interests beyond the borders of San Francisco or lived outside the city and worked within it. For them, confinement in the city posed the threat of severe economic hardship, and this prospect caused some to suppress their concerns for personal safety. Reports of what had happened to people who submitted to inoculation first appeared in the press on May 22. They were not encouraging. On that date, for example, the Record-Union quoted the Chinese consul general as saying that many of the Chinese who had been inoculated, his own clerk among them, were deathly ill and that this was well known throughout the community. ${ }^{108}$ The next day Chung Sai Yat Po published a detailed account of the sufferings endured by two Chinese who had submitted to vaccination. According to this report, entitled "Zhao and Shen's Case Is a Warning to Us," one young man named Zhao had received an injection of

104. Chung Sai Yat Po, May 22, 1900, at 8, cols. 1-2.

105. Strikes Goes on, Chung Sai Yat Po, May 21, 1900.

106. Sacramento Record-Union, May 22, 1900, at 8, cols. 1-2.

107. A Notice Given by the Wicked Health Officers, Chung Sai Yat Po, May 21, 1900.

108. Sacramento Record-Union, May 22, 1900, at 8, cols. 1-2. 
the vaccine in the stomach, whereupon he had begun to run a fever and suffer excruciating pain. Shortly after arriving home he had lost consciousness, and his father had to summon a physician. Another Chinese had a similar experience. He had, said the paper, been injected at the wharf upon returning to San Francisco (from across San Francisco Bay, one may guess), had almost immediately begun to suffer pain, and had gone to the offices of the Six Companies to complain. He there collapsed and seemed about to expire until a doctor was able to revive him. Word of his condition spread and a noisy crowd of several hundred gathered at the Six Companies building. ${ }^{109}$

Incidents of this sort dramatized to the Six Companies leadership and to Consul Ho the need to take more forceful initiative than had theretofore been taken if they hoped to preserve their authority in the community at large. The step that they decided to take was one that the Chinese had over the last 50 years become used to taking when they felt themselves pushed into a corner by adverse governmental action: They sought recourse and protection in the courts.

On May 24, 1900 a bill of complaint was filed by the prominent law firm of Reddy, Campbell, and Metson, a firm under retainer to the Six Companies, in the United States Circuit Court for the Northern District of California on behalf of one Wong Wai, a Chinese merchant engaged in business in San Francisco. Named as defendants were J. J. Kinyoun and all of the members of the San Francisco Board of Health. The complaint averred that the defendants had adopted a resolution requiring all residents of the city to be inoculated with Haffkine's prophylactic vaccine and as a means of enforcing the order were refusing the Chinese the right to leave the city unless they submitted to inoculation. ${ }^{110}$

The bill went on to allege that the vaccine in question was an experimental drug of high toxicity whose efficacy had not been conclusively demonstrated and that under the best of circumstances it was of use only as a plague preventive. It was useless where plague did not exist, and plague did not exist in San Francisco. ${ }^{111}$ The actions of the health authorities, urged the complainant, constituted a "purely arbitrary, unreasonable, unwarranted, wrongful, and oppressive interference" with his and his countrymen's personal liberty (the complaint pleaded the impracticality of joining all twenty-five thousand Chinese as complainants and asked the

109. Zhao and Shen's Case Is a Warning to Us, Chung Sai Yat Po, May 23, 1900.

110. Complaint, for Wong Wai case file, paras. II \& IV (cited in note 76). A companion case on behalf of Japanese plaintiffs was filed by the same law firm at the same time; see Obata, Negoro et al. v. Williamson, Civil Case no. 12,938, Nat'l Archives, San Francisco Branch, Record Group 21. Clearly there must have been consultation between the Chinese and Japanese communities about the bringing of these test cases. The decision in Wong Wai made it unnecessary to argue the Obata case.

111. Complaint, Wong Wai case file, paras. V-VII. 
court to see Wong Wai as representative of a class of complainants) and with his and their right to "pursue a lawful business."112 Furthermore, inasmuch as they were directed only against the Chinese, they constituted a denial of "the equal protection of the laws," guaranteed the Chinese by the Constitution of the United States, by law, and by treaty. ${ }^{113}$ He prayed the court, pleading the inadequacy of any remedy at law, to invoke its equitable powers and issue a "provisional injunction" (to be made permanent on final hearing), enjoining the defendants and all persons acting in their behalf from continuing to deprive the Chinese of "their right to freely pass from [the] city and county of San Francisco to other parts of the State of California."114

Accompanying the complaint were affidavits from several Chinese merchants to the effect that they carried on mercantile business throughout the state, that as such they had from time to time to travel beyond the borders of San Francisco, and that on May 23 they had been prevented from going to the city of Oakland across San Francisco Bay by agents of the defendants because they could not produce certificates of inoculation. ${ }^{115}$

The request for a "provisional injunction" was the equivalent of a request for a "temporary restraining order," an ex parte decree that would have halted straightaway, pending a hearing on the merits of the Chinese case, any further implementation of the inoculation plan. ${ }^{116}$ Circuit Judge William Morrow, who heard this request, refused to issue the sought-after provisional injunction but did direct the defendants to appear in his court the next day to show cause why an injunction should not issue. ${ }^{117}$

The hearing, which convened in the circuit court on May 25 before Circuit Judge Morrow and District Judges Hawley and DeHaven, brought out a large crowd, including many prominent members of the Chinese and Japanese communities. ${ }^{118}$ Spokesmen for the Chinese cause were James Maguire, a former judge, appearing on behalf of the Chinese Six Companies, John E. Bennett, appearing for the Chinese consulate, and Samuel Shortridge, another distinguished local counsel, later to be a U.S. senator from California. Shortridge was brought into the case at the insistence of the San Francisco affiliate of the Chinese Empire Reform Association (Pao Huang-hui), a political party founded in 1899 in Canada by the prominent Cantonese activist Kang Yu-wei and seeking the radical reform of the

112. Id. at para. VIII.

113. Id. at para. IX.

114. Id. at 7-8 of complaint.

115. Wong Wai case file.

116. Though it was not cired in the complaint, the authority for federal judges to issue ex parte interlocutory injunctions was to be found in Rev. Stat. 1874, $\$ 718$.

117. Sacramento Record-Union, May 25, 1900, at 8, col. 3 .

118. San Francisco Chronicle, May 26, 1900, at 9, cols. 1-3. 
Manchu government. ${ }^{119}$ One reporter present at the hearing was moved to comment: "The Chinese are represented by an array of legal talent seldom, if ever before, seen in the local courts."120 On the other side was the United States attorney for the Northern District of California, Frank L. Coombs, representing Kinyoun and Charles Weller, an assistant district attorney, representing the other defendants.

For reasons that are not entirely clear (perhaps simply lack of time), no responsive pleadings were filed by either the San Francisco district attorney's office or the U.S. attorney. In lieu thereof, the district attorney submitted a copy of the Board of Health resolution of May 18 declaring its sense that plague existed in the city, and the U.S. attorney produced Wyman's telegram to Kinyoun of May 21 directing him to inform the transport companies that they should not issue tickets to Asiatics. No objection being made, these documents were accepted by the court as the defendants' return to the order to show cause. ${ }^{121}$ It was left to the defendants in oral argument to develop their theory of their case.

In argument ${ }^{122}$ before the court, the attorneys for the Chinese elaborated on the averments in their bill of complaint. They stressed the toxic and experimental character of the Haffkine vaccine, noted its possible ill effects if administered to anyone who might have been exposed to plague, denied that the health authorities had made a case that there was a plague epidemic or that Asians were peculiarly susceptible to the disease, and urged that in singling out the Chinese for inoculation or confinement in the city they were acting arbitrarily and denying to the Chinese the equal treatment that was guaranteed them by both treaty and fundamental law. In support of their argument as to the arbitrary character of the authorities' actions, they noted that the Chinese (and other Asians) were permitted to roam wherever they pleased within the city of San Francisco, hardly a logical decision if the Chinese were thought to be a threat to the general health. They made some new points as well: Maguire argued that the Board of Health did not have the authority sua sponte and was absent sanction by the Board of Supervisors to order measures so far-reaching and extreme. Bennett argued that the federal authorities were acting ultra vires when they sought to restrict the intrastate movement of persons and that the Wyman telegram furnished no authorization for Kinyoun to act as he did.

119. On the Chinese Empire Reform Association see M. H. Hunt, The Making of a Special Relationship: The United States and China to 1914, at 251-53 (1983), and S. H. Tsai, China and the Overseas Chinese in the United States, 1868-1911, at 129-30 (1983).

120. Sacramento Record-Union, May 26, 1900, at 7, cols. 1-2.

121. Opinion, Wong Wai v. Williamson, 103 Fed Rep. 1, 4 (1900).

122. The account of the oral argument that follows is drawn from newspaper reports in San Francisco Chronicle, May 26, 1900, at 9, cols. 1-3; San Francisco Examiner, May 26, 1900, at 2, col. 2; and Sacramento Record-Union, May 26, 1900, at 7, cols. 1-2. 
The chief spokesman for the government was U.S. Attorney Coombs. His strategy was first to establish that plague did exist in the city and then to argue that in health emergencies of this sort the authorities should be given almost unlimited berth in fashioning remedial measures. The court, however, ordered him to address himself only to the allegations of arbitrariness and unjust discrimination raised by the Chinese. To this Coombs could only make the bald assertion, without any offer of proof, that it was well known that Asiatics were peculiarly susceptible to the disease and that this was more than ample justification for the measures being taken. "If the Federal authorities cannot regulate against a class of people in which this disease is most likely to occur, then Congress had no right to pass the exclusion act," 123 he declared.

\section{THE STATE OF PUBLIC HEALTH LAW IN 1900}

In challenging the health measures, counsel for the Chinese were embarking on something of an uphill battle. Public health legislation dated back to time immemorial and boards of health had by 1900 become familiar governmental institutions, ${ }^{124}$ and by that date a body of public health jurisprudence had begun to emerge. There was not a plethora of case authority, but what did exist confirmed that the state's power to make regulations to protect the public health was at the core of the so-called police power. The cases also suggested that both the legislature and administrative agencies such as local boards of health were invested with wide discretion in determining the content of health regulations.

The issue of the limits of health authorities' powers had been raised with some frequency in the last decade of the 19th century in connection with measures that made smallpox vaccination a condition of school attendance. Here the overwhelming weight of authority was that such measures, even though they involved severe restraints on the individual, were legitimate exercises of the police power. One of the first courts to say so was the Supreme Court of the State of California, which in 1890 had rejected a challenge to an 1889 law providing for the vaccination of all children attending the public schools and for the exclusion of the unvaccinated. ${ }^{125}$ The courts had not, however, given legislatures or local health authorities carte blanche in designing public health measures, nor had they said that such measures, simply because they had been duly adopted, were insulated from court scrutiny. Those tribunals that had sustained,

123. San Francisco Chronicle, May 26, 1900, at 9, cols. 1-3. The "exclusion act" referred to was presumably the first federal law excluding Chinese laborers, passed in 1882.

124. New York City had established its Metropolitan Board of Health in 1866. On the history of public health bodies, see G. Rosen, A History of American Public Health (1958).

125. Abeel v. Clark, 84 Cal. 226 (1890). 
for example, compulsory vaccination had usually made clear that such measures, like all other exercises of the police power that restrained individual liberty, needed justification and could be blocked if they smacked of arbitrariness or did not seem warranted by the facts.

Perhaps the leading case in the area was the recently decided one of Blue v. Beach. ${ }^{126}$ There a group of parents had unsuccessfully challenged a Terre Haute mandatory school vaccination ordinance. "As a general proposition," the Indiana court had said, "whatever laws or regulations are necessary to protect the public health and secure public comfort is a legislative question, and appropriate measures intended and calculated to accomplish these ends are not subject to judicial review."127 But this did not mean that public health measures were totally immune from judicial scrutiny. Indeed, the Indiana court had gone on to say that it was the right, nay the duty, of courts to inquire whether health measures that impaired personal liberties were in fact related to and appropriate to securing their purported object. A public health measure that could be shown to be truly arbitrary, the court had declared, should not be permitted to stand. ${ }^{128}$

\section{JUDGE MORROW'S DECISION}

The man in whose hands the decision in the Wong Wai case chiefly lay, Judge William Morrow, had been a federal judge since 1891. Before that he had served three terms as a Republican member of the House of Representatives. While still involved in partisan politics he had hardly distinguished himself by any special solicitude for the Chinese. Morrow described them in one of his speeches as a class "destitute of moral qualities" and once referred to the Chinese Six Companies as the ultimate power enforcing the servitude of the Chinese masses. ${ }^{129}$ Antipathy toward the Chinese had not, however, noticeably influenced his judicial behavior. For example, he ruled in 1896 that pursuant to section 1 of the Fourteenth Amendment, Chinese children born in the United States were citizens, notwithstanding the inability of their parents to become naturalized. ${ }^{130}$ And on May 28, speaking for a unanimous panel, he handed down an opinion vindicating the Chinese claims.

126. 56 N.E. 89 (1900).

127. Id.

128. Id.

129. Hon. W. W. Morrow, "Chinese Immigration," speech delivered at dinner of the Merchants Association of Boston, Dec. 29, 1886, in H. Wagner, ed., Notable Speeches by Notable Speakers of the Greater West 223-24 (1902). The Six Companies was believed by many, quite without foundation, to be in the business of importing Chinese laborers.

130. In re Wong Kim Ark, 71 Fed. Rep. 382 (1896), aff'd United States v. Wong Kim Ark, 169 U.S. 649 (1898). 
As a preliminary matter, Morrow had to deal with a parol objection to his court's equitable jurisdiction interposed by government attorneys during oral argument. They contended that injunction was an improper remedy for the complainants to be seeking inasmuch as this equitable remedy lay only to prevent interferences with property rights, and the gravamen of the Wong Wai bill was restraint on personal liberty. Morrow disposed of this objection rather summarily:

The cause of action is not merely that the complainant is deprived of his personal liberty. He and a number of others similarly situated are being deprived by the defendants of the right to travel [my emphasis] from San Francisco to other parts of the state in pursuit of lawful business, and this right, it is alleged, has a pecuniary value to the complainant in excess of the amount required to give this court jurisdiction of the case. The permission to travel being by the acts of the defendants coupled with an alleged unlawful condition or restriction, it is the province of the court to inquire into the facts and remove the restriction, if found unlawful. ${ }^{131}$ [Citing, interestingly, a series of cases where courts had granted injunctions in labor disputes.]

He then proceeded to the merits of the case.

He first raised questions concerning the authority of the Board of Health to act as it was acting. The alleged basis for its action was the resolution of May 18, but the legislative authority of the board seemed rather narrowly circumscribed by the city charter. It had authority to "enforce all ordinances, rules and regulations which may be adopted by the supervisors for the carrying out and enforcement of a good sanitary condition in the city, and for the protection of the public health." It also had the limited authority to draft and submit to the supervisors for approval such ordinances, rules, and regulations as it might deem necessary to promote the public health. But nowhere did the charter appear to give it the authority to legislate sua sponte. Then, too, the extremely vague quality of the resolution in question did not escape Morrow's notice. "The resolution of the board of health furnished to the court fails to disclose the method it has adopted [for promoting the public health] under the conditions it has declared to exist."132 Morrow felt no need to dwell on the question of whether the board had adequate authority to do what they were doing. (The court also questioned the authority of Kinyoun, noting that there had been no presidential finding that plague existed in San Francisco as the 1890 statute seemed to require and that Wyman's telegram said nothing about compulsory inoculation. ${ }^{133}$ Its actions, whether

131. Wong Wai v. Williamson, 103 Fed. Rep. at 4-5 (1900).

132. Id. at 5.

133. Id. at $8-9$. 
authorized or not, were from a constitutional viewpoint clearly infirm.

The court recognized that public authorities were often presented with unexpected emergencies affecting the public health and should have wide discretion in devising means of dealing with them. But, citing Blue v. Beach, it noted that these means could not be arbitrary. And that was the problem with the measures adopted by the health authorities. They were, wrote Morrow, cutting to the pith of the matter, "not based upon any established distinction in the conditions that are supposed to attend this plague, or the persons exposed to its contagion," but were "boldly directed against the Asiatic or Mongolian race as a class, without regard to the previous condition, habits, exposure to disease, or residence of the individual," on the supposed rationale that this race was more liable to the plague than any other. And when in oral argument counsel for the defendants was asked to substantiate this claim, he could not offer a shred of evidence. ${ }^{134}$

Those features of the authorities' actions that would have rendered them suspect, even had they not been directed against a racial minority, did not escape comment. The court noted, for instance, that while those subject to the order were being forbidden to leave the city without inoculation, no limits were placed on their freedom of movement within the city. ${ }^{135}$ The surgeon general had himself cautioned public health officials that Haffkine's vaccine was strictly a preventive drug and that it should not be administered to anyone who might have been exposed to infection-its administration to such persons being highly dangerous. Yet everyone subject to the order, irrespective of possible previous exposure to the disease, was being required to submit to inoculation. ${ }^{136}$

It was, however, the racially discriminatory character of the health officials' actions to which Morrow felt compelled to return, and it was this that condemned them decisively in his eyes. It was this feature of the inoculation campaign that put it in clear violation of the equal protection clause of the Fourteenth Amendment, which guaranteed that Asians, absent some compelling reason, should be subject to the same restrictions and conditions for the benefit of the public health as the members of other ethnic groups. And Morrow saw fit to adduce as precedent two previous ninth circuit cases where the court had invoked the Fourteenth

134. Id. at 7.

135. Id. at 6 .

136. Id at 7-8. Wyman's original telegram of March 6, 1900, had made a distinction between Haffkine's vaccine and Yersin's serum, but no evidence was presented to the court that such a distinction was being made in the inoculation campaign then underway. The court did not note one other curious feature of the inoculation campaign. Apparently a single injection with Haffkine's vaccine was enough to obtain a certificate and free one from the supervision and control of the health authorities. However, the established medical wisdom at the time was that a single injection would confer no lasting immunity but rather needed to be followed by a second one if the procedure were to be efficacious. 
Amendment to nullify the anti-Chinese actions of local officials. In the 1879 case, Ho Ah Kow v. Nunan, the court had struck down on equal protection grounds the San Francisco ordinance that would have required the shearing of the hair of all prisoners in the county jail to within an inch of the scalp, thus humiliating Chinese prisoners. And in the more recent 1890 decision In re Le Sing, the court had invalidated an extraordinary local ordinance that would have forced all Chinese either to leave San Francisco or remove from Chinatown to an officially demarcated ghetto elsewhere in the city. ${ }^{137}$

On the same day the decision was handed down, U.S. Attorney Combs sent a telegram to his superior, tersely noting its terms and rationale. "The matter," he said, "was argued and well considered on its merits."138 A few days later he wired again, this time striking something of a more defensive tone, contending that the outcome was a surprise to all and that it might have been different had the court not refused his offer to demonstrate that plague did exist in San Francisco. He did not suggest that the decision be appealed, nor did he think there was any reason for further involvement by the federal quarantine officer. "The local Board of Health has now taken hold of the matter and I think it can safely be left to its authority," he declared. ${ }^{139}$

\section{THE LOCAL AUTHORITIES CONSIDER A NEW STRATEGY}

By the time Coombs sent his second telegram, the San Francisco Board of Health had taken hold of the matter, as he put it, and was busy implementing a new plan for containing the bubonic plague outbreak. It had not done so entirely on its own initiative, however. It had acted mainly in response to an ultimatum that it had received from the state Board of Health.

The state board, charged with protecting the health of the state as a whole, had, as events unfolded in San Francisco during the spring, become increasingly apprehensive about the possible spread of bubonic plague to other California communities. As the weeks passed it grew equally concerned about the increasing attention being given to the San Francisco situation by the out-of-state news media and by the actions being taken in reaction to the news by some out-of-state health authorities. ${ }^{140}$ At its May

137. Id at $9-10$.

138. Telegram from Coombs to attorney general, May 28, 1900, Nat'l Archives, Record Group 90 (cited in note 47).

139. Id., May 31, 1900.

140. Several out-of-state newspapers carried stories about the San Francisco plague situation. The May 27 issue of the New York Herald devored the whole of page one of its sixth section and more to coverage of the worldwide plague pandemic. The banner headline ran 
21 meeting held in San Francisco, the state board heard reports that the city of New Orleans was refusing to permit Chinese, Japanese, or poor whites from San Francisco to travel there and would not receive certain classes of freight. More important, the state health officer of Texas was quarantining at the border all passengers and freight destined to Texas points from San Francisco. The board's response was to send notice to health authorities across the country, acknowledging that a limited. number of plague cases had previously been discovered in San Francisco (all "Chinese found dead in their unsanitary quarters") but informing them that there were no longer any cases to be found and that the San Francisco health authorities were implementing every precaution to see that they did not recur. The board ordered a special telegram sent to the Texas state health officer, urging him to remove the quarantine on goods and persons from California or at least modify it to apply to Chinese only. ${ }^{141}$

When Judge Morrow and his colleagues nullified the main precaution the San Francisco authorities were taking against the plague menace, the state board, keen to impress those outside the state's borders with the seriousness of California's commitment to contain the plague outbreak, was quick to react. Within hours of the handing down of the circuit court decision, the board convened in special session in San Francisco. In attendance at the meeting were federal and local health officials, officers of the railroads, and a fair cross-section of the San Francisco mercantile community. At the outset one board member introduced a resolution urging the counties contiguous to the city and county of San Francisco to close their gates to the entry of Chinese or Japanese from the city. No one bothered to reflect on how such a racially partial ban on travel between counties would comport with the sense or spirit of Judge Morrow's decision, but several businessmen were quick to point out how counterproductive such a resolution could be from a commercial standpoint. The freight manager of Southern Pacific said, in view of the free intercourse between Orientals and Caucasians within the city ("they wash our clothes; they are in the houses as servants") he did not see how the resolution could be limited to Orientals alone. It would have to apply to everyone, and that would amount to a statement that plague was epidemic in San Francisco and a declaration of a self-imposed quarantine. The vice president of the

\footnotetext{
"Bubonic Plague: Life's Most Awful Enemy: It Has Ravaged Continents and Decimated Populations, Finally Securing a Foothold in the United States." The story featured interviews with the prominent New York physicians, $D_{r}$. George Schrady, editor of The Medical Record, and Dr. A. H. Doty, Health Officer of the Port of New York. Notwithstanding the headline, neither expressed great concern about the plague reports emanating from San Francisco.

141. Minutes of the state Board of Health meeting, May 21, 1900, can be found in the Wong Wai case file (cited in note 76). See also Sacramento Record-Union, May 22, 1900, at 8, cols. $1-2$.
} 
railroad endorsed this view, predicting that the measure would cause other states to follow the example of Texas and "bar their ports to the products of this state." Both urged the board to exercise the utmost care and prudence in whatever it decided because its decision could affect the entire industrial economy of California.

The first trial balloon having been quickly punctured, those present at the meeting seemed at a loss as to what steps to recommend, so the discussion for a time meandered aimlessly. The logjam was finally broken by a suggestion from Dr. W. F. Blunt, the health officer of Texas. Blunt had been in the city for several days on a mission of investigation and had been invited to observe the board's proceedings. He rose to say that he was surprised at the extent to which whites and Chinese freely intermingled. He thought it would make much more sense from a public health standpoint if the Chinese were strictly confined to one district and no intercourse with them permitted. "Put on a strong quarantine on Chinatown, allow no citizen to go in or out," he declared, and he would, after 30 days, advise lifting Texas's blockade of California goods. The suggestion met with immediate, enthusiastic approval from all present, one merchant even volunteering to finance a volunteer "pickax" brigade to keep the Chinese in Chinatown should the local constabulary prove unequal to the task. The members of the San Francisco Board of Health who were present were instructed that they should proceed forthwith to have Chinatown quarantined. ${ }^{142}$

That same day, the San Francisco Board of Health met to consider the state board's request. A large number of the city's merchants were present at this meeting as well, and many lent their strong support to the state board proposal. One member voiced an objection to the proposal, claiming that it amounted to a ban on travel based on race and as such was in conflict with the Wong Wai decision. A merchant interposed (disingenuously?) that this was not the case inasmuch as Judge Morrow's decision forbade legislation aimed at a particular racial group ("class legislation") whereas the state board proposal was aimed only at a particular urban district. One obstacle that the Wong Wai decision did put in the way of any board action, all agreed, was its ruling that the board needed the sanction of the board of supervisors before implementing measures of this sort, and so a resolution was moved and approved to ask the board of supervisors for authority to quarantine Chinatown. ${ }^{143}$ The supervisors' decision became a foregone conclusion when a state Board of Health representative told them that if they did not quarantine Chinatown the state would order

142. Account of state Board of Health meeting May 28, 1900, taken from San Francisco Call, May 29, 1900, at 1, cols. 2-3 \& 2, cols. 2-3.

143. Account of San Francisco Board of Health meeting based on story appearing in the San Francisco Examiner, May 29, 1900, at 12, col. 3. 
the whole city quarantined (an odd ultimatum in light of the distinctly negative reaction the Henderson resolution had provoked at the state board's May 28 meeting). The resolution that was passed authorized the Board of Health to "quarantine persons, houses, places, and districts within the city and county when in its judgment it is deemed necessary to prevent the spreading of contagious or infectious diseases."144

When the city Board of Health, now armed with full power by the San Francisco supervisors, reconvened on May 29, it heard further arguments in support of the Chinatown quarantine. A spokesman for the fruit canning industry contended that even though there was no proven plague epidemic and few alleged cases had been discovered, many outside the city and state were convinced that the disease did exist and something needed to be done to allay those concerns. Moreover, there was the state board's threat to quarantine the entire city if proper precautions were not taken. Dr. Kinyoun, who had apparently not heard or not heeded the U.S. attorney's advice that federal officials stay aloof from the matter, also spoke. Chinatown would always be a focus of plague infection, he said, and ought to be cordoned off from the rest of the city. This should be followed by a systematic inspection of the district with the removal of confirmed plague cases to a hospital and suspicious cases to a detention center. He also called for the systematic destruction of rats, which he said served as a vehicle for disseminating contagion, the first time that this was brought to the fore as a means of combating the plague. ${ }^{145}$ The board then passed a resolution quarantining the district of San Francisco bounded by Kearny, Broadway, Stockton, and California streets. When the chief of police pointed out that there were a handful of whites living in the proposed district, it was resolved to leave it to the discretion of the health officers and the chief of police to modify the lines of quarantine to take this into

144. San Francisco Chronicle, May 30, 1900, at 9, col. 5. According to the San Francisco Examiner, May 30, 1900, at 3, col. 1, a reporter for a Chinese newspaper, several Chinese merchants, and Thomas Riordan, an attorney who frequently represented Chinese in civil rights litigation, were present at this meeting.

145. Kinyoun, like many others in the health field at the time, understood that rats played a most significant role in the transmission of bubonic plague but did not understand, and admitted as much, what the exact mode of transmission was. In a talk that he gave to the Medical Society of the State of California in April 1901, he declared that the plague was "primarily a rat disease, becoming secondary to man" and that the rodent was probably the chief agent of the disease's dissemination. The reason that rats were stricken first, he thought, was that they had more opportunity for contact with "infected material," i.e., the discharges of the sick. Laboratory experiments, he acknowledged, had demonstrated that fleas could transmit the disease from rat to rat but it had not been shown that they could transmit it from rat to man. "... the exact manner of the spread of plague from rat to man is not known," he told the society. On the other hand, he had "no doubt that the disease can be and is transmitted from person to person, by direct contact with the discharge of those sick." He also asserted that there was no doubt that the mild form of bubonic plague known as pestis minor could be spread in the same way. His remarks appeared in the Occidental Medical Times, August 1901, at 4-6. 
account. ${ }^{146}$ To cap matters off and eliminate all doubts as to authorization, the board of supervisors on May 31 passed an ordinance ratifying the health board resolution and reconfirming its authority to implement quarantine of the designated district. ${ }^{147}$

\section{THE SECOND QUARANTINE OF CHINATOWN}

The chief of police did not wait long to implement the board's resolution. A force of 159 police was detailed in three watches to enforce the decree. ${ }^{148}$ Fifty-three were sent immediately to the district to guard all points of ingress and egress. ${ }^{149}$ A newspaper reporter noticed that there were a few buildings fronting on the borders of the quarantine district that were occupied by Caucasian residents or business establishments. These were left out of the quarantine district, although their entrances were guarded. "By a careful discrimination in fixing the line of embargo," he commented, "not one Caucasian doing business on the outer rim of the alleged infected district was affected."150 This anomaly did not go unnoticed by the Chinese or their attorneys. Shortly after the quarantine was put in force, Mayor Phelan gave a statement to the Associated Press to the effect that nine dead bodies showing evidence of plague had been removed from Chinatown in the past two months but that there was no evidence of infection in the city proper. As a result, quarantine measures had been adopted "in order to protect outside territory from even the remotest possibility of contagion." They were, he stressed, "merely precautionary."151

In the immediate aftermath of the board action, Samuel Shortridge, one of several attorneys under retainer to the Chinese Six Companies, told a reporter for the San Francisco Examiner that legal action was probable. "The passage of the order was done in such a hasty manner that it may be vulnerable," he said. And he pointed out what the likely area of vulnerability was. The city authorities seemed to be under the impression that the only infirmity in their previous health measure (the one invalidated in the Wong Wai case) was the lack of supervisorial sanction for the health officials' action. But, as Shortridge commented, that was only part of the problem. There was the larger question of the substantive reasonableness of this new interference with the personal liberty of the Chinese residents of San Francisco. "That was the basis of Judge Morrow's deci-

146. San Francisco Call, May 30, 1900, at 2, cols. 3-4.

147. For text of the ordinance see case file, Jew Ho v. Williamson, Nat'l Archives, San Francisco Branch, Record Group 21 (U.S. Dist. Ct. N. Dist. Cal., File No. 12,940) (hereafter "Jew Ho case file").

148. San Francisco Examiner, May 30, 1900, at 3, cols. 1-2.

149. San Francisco Chronicle, May 30, 1900, at 9, col. 5.

150. Id.

151. San Francisco Call, May 30, 1900, at 2, col. 4. 
sion in the other case," he noted, "and although the court indicated the board of supervisors as the proper body to make regulations of this sort, it does not follow that its acts are not subject to review by the courts." 152

The statement issued the next day by the Chinese Six Companies itself was more cautious than Shortridge's. It began with a pledge not to take precipitate legal action and requested that if bubonic plague in fact existed (something it did not concede), no expense be spared to stamp it out. It requested that the sanitary measures that the health authorities had been pursuing for some time be continued and promised Chinese cooperation. It did, however, pose the interesting question why, if there was a belief that a contagious disease, bubonic plague, existed in Chinatown, nothing was being done to protect the Chinese living in the-district from infection. Why, for example, were the authorities not quarantining the individual buildings in which suspected plague cases had been found but rather allowing the residents of these places to mingle freely with the other inhabitants of the district. The statement included a plea that the city begin to think about how it intended to feed and care for the thousands of Chinese now effectively incarcerated in Chinatown, many cut off from all means of earning their livelihood. ${ }^{153}$ Consul General Ho Yow, who issued a statement the same day, was quite blunt in arguing that the city was under an obligation to care for the Chinese community at public expense, ${ }^{154}$ a view that Judge Maguire, another legal counselor to the Six Companies, echoed. "It has been held by some of the highest courts that persons in quarantine are in the same position as public prisoners and ... [are] therefore ... properly a charge on the public Treasury."155

Caucasian reaction to the new board action was mixed and initially, at least, followed along partisan lines. The editorial writers of the Chronicle saw everything through party-political lenses. To them this was but another instance of incompetence on the part of Mayor Phelan, his allies on the board of supervisors, and the political hacks they had appointed to serve on the Board of Health. ${ }^{156}$ The Chronicle never relented in its insistence that there was no plague in the city and that to suggest otherwise constituted high treason against the reputation and economic interests of San Francisco. The Hearst-owned Examiner, on the other hand, which had from the beginning been generally supportive of official action, continued in its support. To it the latest measures adopted by the Board of Health were well calculated to deal with the situation in Chinatown, to protect the health of other San Franciscans, and to allay the concerns of

152. San Francisco Examiner, May 30, 1900, at 3, col. 3.

153. Sacramento Record-Union, May 31, 1900, at 8, col. 4.

154. San Francisco Examiner, May 31, 1900, at 3, cols. 5-6.

155. Id.

156. San Francisco Chronicle, May 30, 1900, at 9, col. 5, reaction to announcement of quarantine. 
those outside the city's borders. ${ }^{157}$ If the measures were going to cause serious hardship to the Chinese, the paper could muster up little in the way of sympathy for them. The Chinese, after all, so reasoned the paper, were "unwelcome guests of the city and had brought the plague into it, thereby bringing these measures on themselves." It did not think that they were deserving of any special consideration on the part of other San Franciscans. ${ }^{158}$

The reaction of the San Francisco Call to the second quarantine of Chinatown is instructive. The Call was as bitterly partisan a paper as the Chronicle and all along had faithfully echoed its sister journal's editorial stance that the plague was a concoction of either venal or incompetent health officials. Its first reaction to the quarantine decision of May 29 was to ridicule it, insisting yet again that plague allegations were "false and a fraud."'159 To lend the support of science to this position, the paper brought out to San Francisco at the end of May one Dr. George Schrady, a New York physician with something resembling a national medical reputation. When Schrady said shortly after his arrival in San Francisco that local health officials had not been able to show him a single living case of plague, the Call trumpeted this loudly in a full front-page headline that read: "Board of Health Confesses to a Famous Expert Who Crossed the Continent That There Is No Bubonic Plague in this City." 160 It was put into a highly embarrassing position the next day, however, when Schrady was invited to witness the autopsy on a corpse found in Chinatown, which confirmed the presence of plague germs in the tissue of the deceased. The Call was now forced to do some backing and filling.

It duly printed Schrady's comments, but, seeking to put the best face on them, it also stressed that the New York doctor did not consider his experience any cause for alarm. He in fact had gone out of his way to assure the city's white residents that they need not be concerned about contracting the disease so long as they kept their premises clean and the city continued its sanitation of the Chinese quarter. ${ }^{161}$ In subsequent issues of the paper, Schrady stated more fully his own view of the matter. He reported that he was convinced that there had been sporadic cases of bubonic plague in San Francisco but that these presented no threat to the general population and in no sense constituted an epidemic ("One swallow does not make a summer, and one case of plague does not make an epi-

157. San Francisco Examiner, June 1, 1900, at 6, cols. 1-2.

158. San Francisco Examiner, June 3, 1900, at 26, col. 1. These remarks were specifically directed at Ho Yow's request that the city assume responsibility for provisioning Chinatown.

159. San Francisco Call, May 30, 1900, at 6, col. 1.

160. Id., May 29, 1900, at 1. The Chinese daily, Chung Sai Yat Po, also interpreted Schrady as flatly denying that there was (or presumably ever had been) any outbreak of bubonic plague in Chinatown. See article entitled No Evidence to Produce, May 30, 1900.

161. San Francisco Call, May 31, 1900, at 1, cols. 1-3. 
demic"). The authorities, he thought, were taking proper steps, including the quarantining of Chinatown, to contain the disease, and he thought that these measures were entirely to the benefit of the city's Chinese population. ${ }^{162}$ "The Chinese should consider that this movement is for their good," he wrote in one article that appeared in Chinese translation on the same page, "the white man is a friend to the Oriental, in spite of what is said to the contrary." 163 He thought the quarantine of California goods that had been imposed by the state of Texas entirely unwarranted and thought, finally, that one benefit of the entire episode was to alert San Francisco to the generally unclean condition of Chinatown and the need to do something about it. ${ }^{164}$

These were views that the Call could live with, without suffering too much embarrassment about its previous editorial posture. Yes, the paper said, there may have been sporadic cases of plague, but no, these did not constitute an epidemic. "If there was the slightest fear that San Francisco was to become the sufferer of an epidemic of the dread disease the apprehension has passed away," it wrote. ${ }^{165}$ It agreed with Schrady that one benefit of the whole affair was to alert the city to the pressing necessity to do something about Chinatown, and it did not mince words about what it thought needed to be done. The acerbic rhetoric it usually directed at the city fathers it now aimed at the Chinese community:

In no city in the civilized world is there a slum more foul or more menacing than that which now threatens us with the Asiatic plague. Chinatown occupies the very heart of San Francisco. ... So long as it stands so long will there be a menace of the appearance in San Francisco of every form of disease, plague and pestilence which Asiatic filth and vice generate. The only way to get rid of that menace is to eradicate Chinatown from the city. . . . Clear the foul spot from San Francisco and give the debris to the flames. ${ }^{166}$

\section{THE MASS REMOVAL OF THE CHINESE AND RAZING OF CHINATOWN CONSIDERED}

The Call's was not the only voice now being heard in favor of using the torch to combat the plague, a measure that would have driven the plague-infested rats to other parts of the city, thereby assuring the widest possible dissemination of the disease. Indeed, it might almost be said that

162. Id, June 2, 1900, at 1 .

163. Id.

164. Id.

165. Id., June 1,1900 , at 2 , cols. $1-2$.

166. Id, May 31, 1900, at 6, cols. 1-2. 
something of a consensus was beginning to emerge on the subject in the lay and scientific communities alike. Schrady himself had referred to this possibility on two separate occasions. In his May 30 report for the Call he said that every infected house in Chinatown should be emptied of its inhabitants and either thoroughly disinfected or burned to the ground. ${ }^{167}$ More significantly, in an interview he gave the same day to Chung Sai Yat Po, he spoke of the possibility of having to raze the entire quarter, though he did not advocate such a step. He thought it would be a fairly simple matter, he had told the paper's reporter, to evacuate the Chinese from the district, rebuild a new Chinatown on the ashes of the old, and compensate everyone for any property lost. And he cautioned the Chinese against taking such a measure amiss should it eventually prove necessary. A decision to burn Chinatown, he assured his interlocutor, should be seen as betokening love and concern rather than hatred for the Chinese. ${ }^{168}$ The bluntest comment (and it was quickly picked up and publicized by the Chinese press) had come from D. D. Crowley, a member of the state Board of Health. "I would advocate," he said, "the complete destruction of Chinatown by fire as the best and safest method of stamping out the plague." He pointed with approval to the example of what had happened in December of the previous year in Honolulu, where a so-called sanitary fire designed to burn down the residence of a plague victim had gone out of control and destroyed the whole of Honolulu's Chinatown. ${ }^{169}$

A reporter who toured Chinatown the day after the imposition of the quarantine commented that it had the look of a besieged city. The area was surrounded by armed guards, and within it, he wrote, "business has been suspended, stores are closed, doors barred, and the Asiatics gather on the street corners, excitedly gesticulating while they discuss the embargo placed upon them, much as inhabitants of a beleaguered town might be expected to do."170 One can be certain that the remarks of Schrady and Crowley, which appeared the next day in the Chinese press, did nothing to alleviate this sense of beleaguerment. A more immediate concern of the inhabitants, however, was the question of sustenance. Many Chinese worked outside the district, and the blockade cut them off from their means of livelihood. Of more importance, the district as a whole was cut off from its sources of food supply, and the effects of this severance began quickly to manifest themselves. On May 31, for example, Consul Ho told the press that there was a sense of a general, serious food shortage in the district and that the prices of the foodstuffs that were available were being bid up rapidly. He described the matter of provisioning Chinatown as one

167. Id, at 1 , cols. $1-3$.

168. Interview with the New York Doctor, Chung Sai Yat Po, May 31, 1900.

169. San Francisco Call, May 31, 1900, at 1, col. 7 .

170. San Francisco Examiner, May 31, 1900, at 3, col. 3. 
of great urgency and implored city authorities to take speedy, decisive action to deal with it. If they did not, he held out the prospect of legal action. ${ }^{171}$

The cooperation that Ho asked for was not forthcoming. The Board of Health did meet on May 31 to discuss the ongoing plague situation, and at the behest of attorneys for the Six Companies, who were present, did take up the question of provisioning Chinatown. It agreed in principle with the Chinese representatives that the city was duty-bound to care for the blockaded residents of the district, but it refused to say what concrete steps it might take in order to deal with the matter. As if to add insult to this rebuff, it took a series of actions that, together, could have only had the effect of exacerbating Chinese anxiety: It ordered that an autopsy be performed on the occasion of any death in the Chinese quarter. The Six Companies, on the request of its lawyers, was given permission to designate a physician to be present. It ordered as well the inspection and, if necessary, fumigation of all Chinese laundries, wherever situated in the city, on the grounds that they might be harboring refugees from Chinatown. Finally, it approved a resolution asking the mayor to enlist the aid of the federal government in securing sites outside the city that could be used as detention centers, it having been shown, the resolution said, that such centers were "well adapted to circumscribe and limit the injurious results of contagious and infectious diseases." They should be able to accommodate up to seven thousand persons. Possible sites mentioned were Mission Rock, a small, barren island about a half-mile offshore, claimed by both the United States and a private proprietor, the California Dry Dock Company, and occupied at the time by the proprietor's warehouses and wharves, and Angel Island, a much larger federal preserve in the middle of San Francisco Bay. ${ }^{172}$

The idea of setting up facilities outside San Francisco where suspected plague victims could be detained originated with Joseph Kinyoun. In midMay he had broached with the Army's representative in San Francisco the idea of using a portion of Angel Island as a camp in case a large number of plague suspects were discovered. (The army's response was that authorization for such use would have to come from the highest levels of the War Department. ${ }^{173}$ ) Kinyoun, who had something of an apocalyptic turn of mind, may indeed have been genuinely concerned about the limited plague outbreak turning into a major epidemic. It seems far more likely, however,

171. Id., June 1, 1900, at 3, col. 5 .

172. See accounts of board meeting in San Francisco Examiner, June 1, 1900, at 3, col. 3; Sacramento Record-Union, June 1, 1900, at 8, col. 1. Text of the resolution in telegram U.S. Sen. George Perkins to Secretary of War Elihu Root, June 2, 1900; National Archives, Record Group 90.

173. See telegrams Maj. Gen. Shafter to Adjutant General, May 22, 1900; Kinyoun to Wyman, May 23, 1900, in Nat'l Archives, Record Group 90 (cited in note 47). 
given what would shortly transpire, that he saw the camp not as a place to harbor plague suspects, but as a place to harbor the mass of the Chinese population pending the razing and rebuilding of the district, an idea for which he had a great deal of sympathy. ${ }^{174}$ In any event, the idea first achieved general public currency when the Board of Health endorsed it at its May 31 meeting, and one of its first effects was to send an immediate shudder through the Chinese community. Chung Sai Yat Po, which reported the board's decision in its June 1 edition, interpreted the resolution as saying in effect that the whole of Chinatown should be evacuated. Not surprisingly, it coupled its report of the proposal with a reminder of the cries then being heard for the razing of Chinatown. Without exactly saying so, it seemed to be intimating that the one action was a natural preliminary to the other. ${ }^{175}$

\section{A CONTRETEMPS INVOLVING CHINESE PHYSICLANS}

In response to the board's decision that it should be permitted to have one of its own doctors present at autopsies conducted in Chinatown, the Six Companies designated three local physicians whom it had retained for this purpose. ${ }^{176}$ Shortly thereafter, another organization, the Chinese Empire Reform Association, through its attorney, sought to secure the same privilege for a physician in its employ. ${ }^{177}$ It was rare at this time to find a Chinese organization other than the Six Companies seeking to negotiate directly with Caucasian authorities on a matter of community concern. It is known that the message of $K^{\prime}$ ang Yu-wei, the Confucian scholar who had founded the reform association, won an immediate, enthusiastic response from the scattered overseas Chinese communities as well as the one in San Francisco. Just how enthusiastic the San Francisco response to K'ang's message must have been can be inferred from the fact that within months of its founding the San Francisco branch had gathered sufficient resources to retain its own physician and legal counselor and felt confident enough of its own standing in the community to seek to act independently of the Six Companies. Its independent action may have betokened as well a certain suspicion of the Six Companies, which was seen, by virtue of its working relationship with the consul general's office, to be too closely connected with the Chinese government of the day. ${ }^{178}$

174. See text infra at note 253 .

175. Tents Are to Be Put Up, Chung Sai Yat Po, June 1, 1900.

176. An Emergency Meeting to Stop Harsh Trearment, Chung Sai Yat Po, June 1, 1900.

177. San Francisco Chronicle, June 2, 1900, at 9, cols. 1-4.

178. It is difficult to gauge exactly how much hostility may have existed between the Empire Reform Association and the Six Companies. It is significant that the reform association used a lawyer, Samuel Shortridge, who often worked for the Six Companies. On the 
The Empire Reform Association's petition for independent representation at autopsies was summarily dismissed. Indeed, the next day the permission granted the Six Companies was revoked due to a serious indiscretion committed by one of its physicians. This man, Ernest Pillsbury, a bacteriologist, had on June 2, without securing advance approval from the health authorities, ordered two other physicians to remove the lymph glands of a Chinese who had died under suspicious circumstances. Upon analyzing the tissue he announced in the face of much contradictory evidence that the deceased had died of syphilis. ${ }^{179}$ When they discovered that this had occurred, the health authorities were apoplectic. The lymph glands were recovered with little trouble, but this did not stop the Board of Health from accusing Pillsbury of trying to destroy evidence and of frustrating the Board's ongoing investigation. In reaction it not only revoked the permission granted him and other Six Companies physicians to witness autopsies, but also declared that in the future no Chinese-employed physicians would be allowed to enter the quarantine district for any purpose whatsoever. ${ }^{180}$ There is no real evidence that Pillsbury was in fact trying to destroy the lymph glands he had ordered removed or to conceal them from the authorities. He seems rather to have been interested in doing his own bacteriological examination. The fact remains that he was guilty of a serious impropriety, and this did serious damage to the Chinesecause. The Chinese do not seem to have been nearly as well served by the physicians as by the lawyers in their employ.

When after several days no action seemed forthcoming from the Board of Health on the request that arrangements be made for the provisioning of Chinatown, the Six Companies had its attorneys write to the board of supervisors with a request that it undertake to do something. ${ }^{181}$ It also persuaded the consul general to ask the legation in Washington to make representations to the State Department about the worsening situation in Chinatown and the local authorities' refusal to address it. ${ }^{182}$ One Chinese merchant, Chue Yet, an officer of the Chinese Merchant's Exchange, took it upon himself to wire Wu T'ing Fang, His Imperial Chinese Majesty's minister to the United States. The telegram complained of the immediate problem brought on by the Board of Health's quarantine decision-the fact that there were now isolated in the quarantine district some

other hand, later in the quarantine crisis a reform association orator was heard accusing the Six Companies of conniving with the city authorities to maintain the quarantine. San Francisco Examiner, June 3, 1900, at 14, col. 5.

179. San Francisco Chronicle, June 2, 1900, at 9, cols. 1-4. The victim had clearly died of plague.

180. Sacramento Record-Union, June 3, 1900, at 5, col. 4.

181. San Francisco Chronicle, June 2, 1900, at 9, cols. 1-4.

182. Telegram dated June 4,1900, from Consul Ho to Minister Wu T'ing-fang, attached to letter, dated June 5, 1900, from Acting Secretary of State David Hill to the Secretary of the Treasury, Nat'l Archives, Record Group 90 (cited in note 47). 
eight thousand Chinese cut off from their means of support. It complained as well of the board decision no longer to permit physicians in Chinese employ to enter the quarantined area and of the great losses being sustained by Chinese merchants. It was above all, however, an attack on the very idea of the general quarantine of Chinatown, one that it characterized as unjustified by the facts and discriminatory in operation. The quarantine, the telegram noted, applied to Chinese only and was enforced "against buildings and persons that have not been infected or exposed" to the alleged plague outbreak. The Chinese had no objection to the quarantine of buildings where alleged plague victims had died but protested against the general quarantine of the entire district. It begged the minister "to lay these matters before the proper authorities, through the proper medium, so that we may be saved from irreparable loss and granted the rights we are entitled to by law and treaty."183

\section{THE QUARANTINE IS TIGHTENED AND THE GROUNDWORK LAID FOR MASS-REMOVAL}

At a meeting held June 4, the San Francisco Board of Health, prompted by pressure from the city's white merchants, decided on yet sterner measures incidental to the quarantine. ${ }^{184}$ Among them: the halting of all streetcar traffic through Chinatown (streetcars had theretofore been allowed to pass through so long as they did not stop); the doubling of the police guard on the district's perimeter; and the use of barbed wire wherever feasible to seal in the area. ${ }^{185}$ Much more important, it made an announcement that must have taken many by surprise, especially the Chinese. It reported that it had already secured the consent of the California Dry Dock Company to use its docking facilities on Mission Rock and that "steps were underway" to begin sending the next day the first of the fifteen hundred Chinese it expected to quarter there. In the meantime, it said, discussions were proceeding to secure from the federal government a much larger facility on Angel Island, one that could accommodate eight thousand persons. ${ }^{186}$ The board resolution of May 31 had been couched in terms of negotiations with the federal government for the use of facilities in its control, suggesting a process that might take some time. What now became clear was that the board had been unwilling to await the result of these negotiations but had rather decided to enter into negotiations

183. Telegram dated June 4, 1900, from Chue Yet, Chinese Merchants Exchange, to the Chinese Minister in Washington, attached to letter cired supra note 182.

184. Both the San Francisco Examiner, June 4, 1900, at 3, cols. 1-2, and San Francisco Call, June 5,1900 , at 12 , col. 2, attributed the motivation for the stricter measures to pressure from merchants.

185. San Francisco Chronicle, June 5, 1900, at 7, cols. 3-4.

186. San Francisco Call, June 5, 1900, at 12, col. 2. 
of its own that would secure the quick availability of a detention site. It was significant too that the board announcement of an imminent deporta: tion was not accompanied by any finding of the sudden discovery of a large number of plague suspects in Chinatown. Given the wording of the announcement and the context in which it was issued, ${ }^{187}$ the proposed board action could only be seen as the first step of an operation aimed at some sort of mass removal of the Chinese from San Francisco. And it was so interpreted by the Chinese.

The Chinese reaction to the board announcement was one of indignation and defiance. Consul Ho undoubtedly spoke for the whole community when he told a reporter: "The feeling among the Chinese is such that they would prefer to risk their lives rather than be compelled to remain in the power of the American physicians for an indefinite period." 188 As if to underscore this comment, the Six Companies, hardly a radical organization, announced the next day that any attempt by the Board of Health to remove the Chinese from Chinatown would be resisted, if necessary, by force. ${ }^{189}$

Another means of resistance was, however, available. Notwithstanding the Six Companies' pledge in the immediate aftermath of the blockade not to take precipitate legal action, the possibility of litigation was never very far from the minds of the Chinese leadership. Indeed, the evidence would suggest that they began to lay their litigation plans very soon after the blockade began. They held them in abeyance for some time while they sought to sort out exactly what was happening and on the thought perhaps that some sort of compromise might yet be worked out with city health officials. But the course of events, in particular the worsening living conditions in Chinatown, was limiting their freedom of action more and more. ${ }^{190}$ The established leadership must have felt some additional concern when the competitor organization, The Chinese Empire Reform Association, announced on June 3 that it intended to go to court shortly to force the authorities to justify their actions. ${ }^{191}$ The Board of Health announcement of June 4 eliminated all room for maneuver, and on June 5

187. San Francisco Examiner, June 5, 1900, at 3, cols. 6-7. One notices that Texas Health Officer Blount, contradicting his previous promises, stated that he would not recommend the lifting of the quarantine on California goods until the San Francisco authorities could assure him that Chinatown "was completely isolated and thoroughly neutralized." $\mathrm{He}$ thought that the only way to accomplish this was to remove all Chinese from "the infected quarter" and destroy it.

188. Sacramento Record-Union, June 5, 1900, at 8, col. 1 .

189. San Francisco Call, June 6, 1900, at 3, cols. 3-5.

190. San Francisco Examiner, June 4, 1900, at 3, cols. 2-3. A journalist who had been allowed to visit the infected district reported, "Men who are accustomed to working by the day are penniless and hungry .... Crowds of these men roam the street sullen and desperate." He noted that the wealthier Chinese were growing more concerned.

191. San Francisco Chronicle, June 4, 1900, at 10, cols. 5-6. 
the Chinese Six Companies, this time joined by the Empire Reform Association, repaired again to the courtroom of Judge William Morrow.

\section{THE CHINESE REPAIR AGAIN TO FEDERAL COURT}

A bill in equity was filed on June 5 in the United States Circuit Court for the Northern District of California on behalf of one Jew Ho, a grocer with a place of business within the limits of the quarantine district. $\mathrm{He}$ complained of an interference with his personal liberty and with his right to carry on his business. ${ }^{192}$ Like the earlier litigant, Wong Wai, he stated that he was bringing suit not only on his own behalf, but also on behalf of the upwards of ten thousand Chinese who resided in the quarantine district, it being impractical to join them all as complainants. ${ }^{193}$ The averments of the complaint, like those of Wong Wai, sought to impress the court with the arbitrariness and discriminatory character of the Board of Health's quarantine resolution, first and foremost the discriminatory character.

The resolution purported to be general in its terms and to impose the same restrictions upon everyone within the quarantine district, but, said the complainant, it was in fact enforced only against the Chinese and not against persons of other races. ${ }^{194}$ Drawing the court's attention to the perimeter of the quarantine district, it sought to show how on virtually every side of the quadrangle instances could be found where Caucasian residences and businesses that lay within the district were not being subjected to quarantine. ${ }^{195}$ A particularly telling allegation concerned the block of Stockton Street on which Jew Ho lived and conducted his business. There, according to the complaint, every other address was occupied by a Caucasian residence or business, and the record showed a perfectly sawtoothed pattern of enforcement-every Caucasian address free of restrictions, every Chinese address subjected to them. ${ }^{196}$ The enforcement of the quarantine in the manner described, the complainant concluded, deprived the Chinese residents of the quarantined district of the equal protection of the laws and their rights and privileges under U.S. law and treaty. ${ }^{197}$

The complaint also spoke in some detail to the allegedly arbitrary character of the quarantine. It first denied that bubonic plague existed or ever had existed in Chinatown, in which case, of course, the imposition of

192. Bill of complaint, Jew Ho case file, paras. V \& XIII (cited in note 147).

193. Id., paras. V \& XIII.

194. The argument here was similar to that made to and accepted by the U.S. Supreme

Court in Yick Wo v. Hopkins, 118 U.S. 356 (1886).

195. Bill of complaint, Jew Ho case file, para. VI.

196. Id.

197. Id. at para. XVI. 
a quarantine was self-evidently arbitrary. ${ }^{198}$ In the alternative, it was submitted, if plague did exist in Chinatown, the board's chosen method of dealing with it was arbitrary and capricious and posed serious threats to the health of the Chinese population. In the first place, the board was quarantining whole blocks of Chinatown on which it never claimed to have found any cases of plague. ${ }^{199}$ By failing to isolate houses where plague had occurred or individuals who it suspected of having had contact with plague victims, and by refusing to permit the Chinese to leave Chinatown, the board was exposing the residents of that district to greater danger of infection. 200

The complaint also faulted the board for failing to provide the indigent Chinese with food and for refusing to permit physicians in the employ of the Chinese to enter the district for the purpose of caring for the sick. $^{201}$ It called attention as well to the proposed imminent evacuation of Chinatown. The defendants, it was said, were in the process of surrounding Chinatown with "a high and substantial fence of posts, beams, and ... lumber." (In the wake of the board's resolution that the perimeter of Chinatown should be secured with barbed wire, the authorities had gone one step further and begun to erect a high wooden wall around the district.) They were threatening, it went on, to maintain this barrier unless and until the Chinese should consent to their removal "to an island in the Bay . . . there to remain during the pleasure of the defendants." 202

The real purpose behind all of the measures described in the complaint, it was claimed, was not to prevent the spread of plague, but rather to prevent the state board of health and health authorities outside of California, themselves acting on unfounded and exaggerated rumors, from levying a quarantine against the city and "for the further purpose of wrongfully, unlawfully, and tyrannically oppressing, annoying, harassing, and injuring" the Chinese. ${ }^{203}$

The complaint concluded with a prayer for equitable relief in the form of a permanent injunction forbidding the defendants from maintaining any quarantine except one limited to such stores, residences, and other buildings as might be found upon proper investigation to be infected with the germs of contagious diseases and to persons found to have been "distinctly exposed to the danger of infection."204

Contemporaneous with the filing of their bill of complaint, the attorneys for the Chinese obtained from Judge Morrow an order to show cause

198. Id. at paras. VIII \& IX.

199. Id. at para. XI.

200. Id.

201. Id. at para. VII.

202. Id. at para. XI.

203. Id at para. VIII.

204. Id. at para. XVIII. 
directing the defendants to appear in his courtroom on June 7 to answer the request for an injunction and a temporary restraining order enjoining the defendants from preventing the physicians in the Chinese employ, so long as they complied with health board rules, from entering Chinatown to examine or attend to the sick. Copies of the complaint and orders were served by the U.S. marshall on each member of the board while it sat in session that afternoon. ${ }^{205}$ Two days later, counsel for the San Francisco Board of Health, clearly not ready to respond on such short notice to the detailed allegations in the Jew Ho complaint, appeared in court to ask for a continuance. The request was granted, the matter being put over until June 13 , on the condition that no action be taken to remove the Chinese to Mission Rock. ${ }^{206}$

In sharp contrast to its curiously lackadaisical procedure in Wong Wai, when it had not seen fit to submit any responsive pleading, relying instead on certain official documents, the board on June 12 filed a lengthy and detailed answer to Jew Ho's bill of complaint, denying or avoiding every material allegation in it. The attorneys for the board, mindful no doubt of the problems it had encountered on this score in connection with its mandatory immunization plan, spent a considerable amount of time first laying out in detail the authority upon which the board had proceeded in implementing its quarantine plan. And here there was no problem in showing supervisory sanction for every step the health authorities had taken. ${ }^{207}$ Having eliminated this as any possible grounds for objection, they proceeded to the merits of the measures that had been adopted. They were, counsel argued, nondiscriminatory and perfectly reasonable in light of all the circumstances.

The defendants denied that the board was singling out the Chinese for discriminatory treatment. The board's quarantine rules, and regulations, they said, were being "enforced equally and similarly against all persons whatever [within the quarantine district] without distinction of race, age, sex, or nationality." 208 As to the alleged nonenforcement of the quarantine against Caucasians on the district's perimeter, the defendants either denied that this was happening or claimed that the Caucasians in question lived outside the affected area. ${ }^{209}$ Quarantine was, the defendants declared, a perfectly reasonable way of dealing with an incipient epidemic of bubonic plague. Its purpose was to prevent "promiscuous communication" between persons within the district where the outbreak was occurring, who were exposed to the danger of contagion, and persons outside

205. San Francisco Call, June 6, 1900, at 3, cols. 2-3.

206. San Francisco Chronicle, June 8, 1900, at 12, col. 1.

207. Jew Ho case file, answer to complainant's bill of complaint, paras. III \& IV (cited in note 147).

208. Id. at para. VI.

209. Id. 
the district, who were free from such danger. ${ }^{210}$ And how had the health authorities determined the precise boundaries of the district where the outbreak was occurring, the district that should be sealed off from the rest of the city? The answer to that question was self-evident to the defendants. Every victim of the bubonic plague, the defendants noted, had been Chinese. ${ }^{211}$ Every case of the disease that had been detected so far had been discovered in that part of San Francisco in which the Chinese clustered, a part of the city with well-recognized borders. ${ }^{212}$ The defendants denied that they were refusing to supply food to the hungry or that they were preventing physicians from entering the district to treat patients. ${ }^{213}$ They conceded that they were erecting a high, wooden barrier around Chinatown but denied that there was anything unusual about this or that they were using the barrier as a bargaining chip to force the Chinese to relocate out of Chinatown to an island in the bay or anywhere else..$^{214}$ They denied finally that either their orders or their actions deprived any Chinese residents of the quarantine district of the equal protection of the laws or of their rights under law and treaty. ${ }^{215}$ The issue was now nicely joined, and the matter was in a good posture for address in oral argument.

Oral argument was held before two of the three judges who had heard the Wong Wai case, Morrow and DeHaven, and consumed two days, June 13 and 14. Counsel for the defendants raised several new points. ${ }^{216} \mathrm{He}$ argued that the court had no authority to inquire into the regularity, legality, or reasonableness of the legislative acts in question. The city had made it clear in its return to the order to show cause that a duly constituted department of the city government had adopted steps that it deemed necessary to deal with a public health emergency, and well-established precedent made it the exclusive judge of the reasonableness of these measures. A federal court, he argued, was without jurisdiction to make inquiry of its own. In support of this proposition he submitted a series of cases in which federal courts had denied themselves the right to inquire into state or local police power measures. In the alternative, citing another line of cases, including the 1887 decision of the U.S. Supreme Court in Mugler ข. Kansas, ${ }^{217}$ he argued that, even if it could examine police power measures, its standard should be one of almost total deference to the will of the legislative body.

A good deal of the debate revolved around the allegedly discrimina-

210. Id. at para. IV.

211. Id at para. $X$.

212. Id.

213. Id. at para. VII.

214. Id. at para. XI.

215. Id. at para. XVI.

216. This part of counsel's argument is inferred from the opinion of the court. See Jew Ho v. Williamson, 103 Fed. Rep. at 16-17 (1900).

217. 123 U.S. 623 (1887). 
tory way in which the quarantine was being implemented. At one point an attorney for the Six Companies, J. C. Campbell, invited the judges to tour the borders of the quarantine district to see for themselves how white residents were being given favorable treatment. The city, while continuing to deny that there was any pattern of discrimination, did concede that along the street that constituted the western boundary of the district, for reasons it could not explain, certain houses were not being subjected to restrictions; and counsel for the city obtained leave to amend his answer so as to redraw the quarantine boundaries to reflect this newly conceded fact. 218

Before the conclusion of oral argument, the attorneys for the Chinese presented to the court some 18 affidavits from licensed San Francisco physicians, three describing themselves as being under retainer to the Six Companies. These attacked the basis for the Board of Health's diagnosis of plague, or, if it could be assumed that plague existed, the methods the board had chosen to deal with the disease. Some of these raised the plausible question why, if a highly infectious disease existed in Chinatown, so few victims had succumbed to it. Others, it must be acknowledged, reflected limited medical knowledge. One, for example, insisted that the microbe that had been isolated in post-mortem examinations was the bacillus that causes hemorrhagic septicaemia (blood poisoning) and not the plague bacillus. 219

The attorneys for the Chinese were able to add to the affidavits of their physicians a statement from a most unlikely ally, the governor of the state, Henry T. Gage. On May 31 secretary of state John Hay had asked Gage to look into a complaint about the quarantine of Chinatown that he (Hay) had just received from the Chinese minister. 220 Gage traveled to San Francisco to conduct an investigation of his own and, on June 13, wired back a report to Hay. Gage had never in his career manifested any particular concern or solicitude for the Chinese, but he was eager to quash the rumor then being "broadcast over the world," as he put it, "of the existence of the dreadful plague in the great and healthful city of San Francisco." He could not find any proof, he said, "that the plague alleged to be here is either infectious or contagious." Certain individuals who had been repeatedly exposed to the disease without taking any precautions had failed to contract it, including members of the family of plague victims and coinhabitants of the same building. He firmly believed that the bubonic plague did not exist or, if it did, the measures being undertaken were un-

218. San Francisco Examiner, June 14, 1900, at 2, cols. 3-4.

219. Affidavit of Dr. Ernest Pillsbury in Jew Ho case file (cited in note 147).

220. Telegram from U.S. Secretary of State John Hay to the governor, May 31, 1900, in Appendix to the Report of the Special Health Commissioners Appointed by the Governor to Confer with the Federal Authorities at Washington Respecting the Alleged Existence of Bubonic Plague in California 15 (Sacramento, 1901) (hereafter "Appendix, Special Health Commissioners' Report"). 
reasonable and discriminatory. ${ }^{221}$

\section{THE RULING IN JEW HO}

The court did not wait long to answer the questions put to it. Stressing the exigent nature of the circumstances that had given rise to the case, Judge Morrow decided to defer the preparation of a written opinion, and on June 15 he summoned the parties and the public to hear his opinion in open court.

After rehearsing the contentions and counter-contentions of the parties, Morrow proceeded to address the defendants' claim that the court did not have the jurisdiction to look into the regularity or legality of the defendants' acts. His response was that the complainants were aliens and were invoking his court's jurisdiction not only on the ground of their specific Fourteenth Amendment equal protection claim, but also on the ground of diversity of citizenship. When a federal court's jurisdiction was invoked on diversity grounds, he pointed out, it had authority to determine all claims raised in the case, whether of a federal or state character, and, just as if it were a state court, might inquire into "all matters [my emphasis] relating to the legality of the restraint imposed upon the complainant. ${ }^{222}$

The court next addressed the argument that once a state or municipality invoked "the general police power" in justification of a measure, its determination was final and the courts were precluded from looking beyond that justification. Morrow, echoing a line of argument he had broached but not pushed very far in Wong Wai, was able to adduce state and federal opinions showing that the police power, while broad, was not unlimited and that it was the proper province of courts, either as a matter of federal or state constitutional law or both, to determine whether governments had stepped beyond the limits established by law. He cited, for example, the 1894 U.S. Supreme Court opinion in Lawton v. Steele, ${ }^{223}$ where the court conceded that a large measure of discretion was vested in the legislature in determining what it ought to do to protect the public safety but at the same time said that a legislature's determination as to whether its exercise of the police power was proper was not final or conclusive but was rather, under the due process clause of the Fourteenth Amendment, "subject to the supervision of the courts."

221. Telegram from the governor to U.S. Secretary of State John Hay, June 13, 1900, in id. at 15-17. Concurring in the governor's conclusion that bubonic plague did not exist were several physicians and a bevy of prominent merchants and bankers.

222. Jew Ho v. Williamson, 103 Fed. Rep. at 16-17.

223. 152 U.S. 133. It is interesting that in Lawton among examples of legitimate exercises of police power cited by the court was the compulsory vaccination of children. 
It also cited Mugler, offered by defense counsel in support of its view, and noted that while Mugler did give wide berth to the police power it also said there were "limits beyond which legislation cannot rightfully go."224 It brought in finally a range of state court opinions-including a California decision nullifying, on both federal and state constitutional grounds, a local health and safety regulation-all of which were in accord that in any measures affecting the property or liberty interests of the citizen the legislature must at least be prepared to show that its exercise of the police power bore some relation to the facts and was not arbitrary or capricious. 225

Having established that the law "as established in the various states of the Union, as well as by the supreme court of the United States"226 permitted him to inquire into the reasonableness of the quarantine of Chinatown, he went on to show why he found the measure unreasonable and therefore invalid. The classical purpose of a quarantine, with respect to infectious and contagious diseases, he noted, was to prevent the spread of disease among the inhabitants of localities. It accomplished this goal by restricting to their houses persons afflicted with the disease or those with whom they had come in contact, thereby reducing the opportunities for the disease to transmit itself from one person to another. But this quarantine had been thrown around an entire section of the city, comprising 12 square blocks and over ten thousand residents. By confining these ten thousand within a limited area and at the same time failing to restrict the movement of the residents of the buildings where the disease was thought to have appeared, the health authorities had in fact increased the danger that these persons would become infected with and spread the disease. Every facility has been offered by this species of quarantine," he declared, "to enlarge [the disease's] sphere and increase its danger and its destructive force." 227

The arbitrary character of the quarantine was, in Morrow's eyes, enough to condemn it. One presumes that had the Board of Health singled out any area of the city for such treatment its actions would have been vulnerable on this ground. But this quarantine had the additional defect of being racially discriminatory, the fact, as Morrow put it, that it "discriminates against the Chinese population of this city, and in favor of the people of other races." 228 Sufficient proof of this for Morrow could be found in the artful way in which the authorities had drawn the boundaries of the quarantine district so as deliberately to exclude residences on the periphery occupied by Caucasians. This, said Morrow, was "in effect, a discrimination" and of a kind that had been "frequently called to the at-

224. Jew Ho v. Williamson, 103 Fed Rep. at 17.

225. Id. at $18-20$.

226. Id at 20.

227. Id. at 22-23.

228. Id. at 23 . 
tention of the federal courts where matters of this character have arisen with respect to the Chinese."229 He quoted liberally from the famous 1886 opinion of the court in Yick Wo v. Hopkins, where a San Francisco ordinance respecting laundries had been found to be discriminatory against the Chinese in its operation. Here, too, according to Morrow, was a case of the "administration of a law 'with an evil eye and an unequal hand" "230 and that under the principle established by the Supreme Court in Yick Wo violated the equal protection clause of the Fourteenth Amendment. ${ }^{231}$

The court ordered counsel to prepare an injunction ordering the general quarantine of Chinatown lifted, although it made clear that it would permit the Board of Health to maintain a quarantine around such places as it believed were infected with contagious diseases. In the event such a quarantine should be imposed, Morrow ordered, a physician selected by the Chinese Six Companies should have the right to attend persons suspected of being afflicted with the disease and the privilege likewise of attending any autopsies that might be made, although Morrow recognized that the health authorities had the right to place reasonable limitations on the privilege. And, aware no doubt of problems that had arisen in the past, he cautioned those who exercised the privilege not to abuse it. ${ }^{232}$ Morrow remarked that if an emergency should arise requiring a modification of his order he would be prepared to issue one. ${ }^{233}$

Within hours, the San Francisco Board of Health convened in special session to act on Judge Morrow's decree. It passed a resolution officially lifting the quarantine of Chinatown and directed the chief of police to remove his forces cordoning off the district. It resolved as well that the physicians for the Chinese should be allowed to attend patients and witness autopsies. Finally, it directed that the general cleaning of Chinatown and fumigation of the district's sewers be continued. ${ }^{234}$ There must have been more than a little resentment in the breasts of the board members. For the second time in less than a month they saw their well-considered plans for dealing with the plague stymied by the intervention of the federal judiciary. At a second meeting of the board held later in the day, a Honolulu physician in attendance commented that only the burning to the

229. Id.

230. Id. at 24.

231. Id. Having already disposed of the issue before the court, Morrow went on at some length (and unwisely it would seem) to discourse upon the question of whether the plague existed at all in San Francisco. He noted that this had nothing to do with the outcome of the case, that the medical testimony was conflicting, and that the court was not being called upon to decide the question, but having said all of that, he could not resist voicing his own personal view that the plague had not existed and did not then exist in San Francisco. Id. at 24-26.

232. Id. at 26-27.

233. According to the report in the San Francisco Examiner, June 16, 1900, at 5, cols. $1-2$.

234. San Francisco Examiner, June 16, 1900, at 5, cols. 1-2. 
ground of the Chinese district had put an end to the plague in his city. ${ }^{235}$ One suspects that more than a few members of the board, hearing this remark, must have thought how welcome the occurrence of just such an accident would be in San Francisco.

One reporter who witnessed the end of the quarantine of Chinatown compared it to the lifting of a siege. "The Board of Health's inspectors broke their encampment in Portsmouth Square," he wrote, "folded their tents and retreated in good order." At the same time "a horde of Chinese poured through the lines like the advance guard of a relief column."236 In short order the district was again presenting to the world the picture of lively bustling commercial activity that it had presented before the imposition of quarantine. "No more sullen crowds gather on the street corners to excitedly discuss the iniquities of the white man," the same reporter commented. 237

\section{FINAL COURTROOM SKIRMISHES}

The main battles had been won, but the Chinese difficulties with the health authorities were not completely over. The Chinese were destined to cross swords with the federal quarantine officer Joseph Kinyoun twice more in federal court.

As it turned out, Kinyoun had anticipated the likelihood of an unfavorable decision in Jew $\mathrm{Ho}$ and had devised a contingency plan for dealing with just such an eventuality. On June 14 he telegraphed his superiors in Washington that, should the federal court order the abandonment of the quarantine of Chinatown, he intended, unless directed otherwise, to introduce strict controls on the travel of all persons leaving San Francisco for out-of-state destinations. ${ }^{238}$ The day the decision was handed down he had served on all transportation companies in the San Francisco area an order directing them not to issue tickets to anyone seeking to leave San Francisco for any destination without a certificate signed by an officer of the Marine Hospital Service. He claimed to be acting under the authority of the law of March 27, 1890 and "the regulations made thereunder and promulgated by order of the President under date of May 21, 1900." His order was made necessary, he explained, "on account of the lifting of the quarantine by order of the Federal Court, thereby allowing people who have possibly been exposed to the infection of plague to leave this city for other states." To enforce the order, he declared, he had stationed federal

235. Id.

236. Id.

237. Id.

238. Text quoted in slip opinion by Judge Morrow in Wong Wai case file, contempt action, at 5 (cited in note 76). 
inspectors at California's borders and had instructed them not to allow any passengers without certificates to pass the state's frontiers. ${ }^{239}$ The regulation promulgated by the secretary of the treasury May 21,1900, it will be recalled, ${ }^{240}$ had authorized officials of the Marine Hospital Service to forbid the sale of transportation services to Asians. Acting, in part, on the basis of that order, local and federal health authorities had put in place the regime requiring Asians to be inoculated with Haffkine's vaccine as a condition of leaving the city, a plan they had been forced to scuttle as a result of the injunction issued in Wong Wai. Kinyoun's June 15 order said nothing about Asians or about Haffkine's vaccine. It was general in its terms. It applied to everyone seeking to leave San Francisco, and the certificate in question was simply an affirmation by a federal health officer that the bearer had complied in all respects with United States quarantine laws and was, in his opinion, "free from the infection of plague or the danger of conveying the same." 241 Notwithstanding the general tenor of Kinyoun's directive, the Chinese perceived the order as aimed really at themselves and moved quickly to challenge it.

On June 16 Wong Wai, the complainant in Wong Wai v. Williamson, and several other Chinese, accompanied by a clerk from the law offices of Reddy, Campbell and Metson, attorneys for the Six Companies, presented themselves at the offices of Joseph Kinyoun in San Francisco. They said that they wanted to travel to other destinations in California and asked Kinyoun to issue them certificates. Their account of what then transpired differs substantially from Kinyoun's, but according to them, Kinyoun refused to issue them the certificates on the grounds that they were Chinese and were inhabitants of the former quarantine district. ${ }^{242}$ Having failed to obtain certificates, they repaired to the circuit court where Wong Wai swore out a complaint praying the court to cite Kinyoun for contempt for violating the injunction the court had issued on May 28.

The contempt proceedings against Kinyoun would probably have turned into yet a third cause celebre between the Chinese and their government antagonists had they not quickly become upstaged by other developments. The Chinese were not the only ones to be offended by Kinyoun's order. Indeed, their reaction may be described as muted in comparison to that of many of the leaders of Caucasian opinion. Governor Gage wired President McKinley that Kinyoun was attempting to quarantine the entire state of California and demanded immediate relief "for the people of this

239. Id. at 5-6.

240. See text accompanying note 96 supra.

241. Sample of a certificate reproduced in San Francisco Examiner, June 17, 1900, at 15, cols. $2-6$.

242. The Chinese account of the events is contained in the affidavits of Wong Wai, Lee Soot, and Milton Bernard accompanying the complaint in the contempt action in Wong Wai case file. 
State, the travelling public, and the commercial interests of the coast."243 The same message of protest was delivered in person to McKinley on June 18 by members of California's delegation to the Republican National Convention, then meeting in Philadelphia. In addition to making the usual arguments about the inappropriateness of Kinyoun's actions, they apparently also told the president that if he didn't act quickly to restrain Kinyoun, California might well be lost to the party in the November elections. ${ }^{244}$ It was enough to do the trick. The president called in his secretary and directed that steps be taken forthwith to set aside Kinyoun's order. ${ }^{245}$ And they were.

The lifting of Kinyoun's restrictions on travel by Californians out of state did not bring an end to the contempt proceedings against himthere was still the issue of whether the federal officer had willfully disregarded a court order-but it took much of the edge out of them. They ground to a conclusion in early July with Judge Morrow holding that there was insufficient evidence to find that Kinyoun was discriminating against the Chinese as a class or was seeking to prevent anyone from travelling from San Francisco to points within California. ${ }^{246}$

\section{CONCLUSION}

Misguided commercial interests, not being used to the disease, objected to the unusual methods proposed for eradication.

\section{Henry B. Hemenway, American Public \\ Health (1916), writing on the San \\ Francisco plague outbreak of 1900}

The events of 1900 left Surgeon Joseph Kinyoun a deeply embittered man. He gave full went to his anger and frustration in a presentation that he made before the Medical Society of the State of California in April 1901.247 It was an extraordinary apologia. He was convinced, he told his fellow physicians, that the plague would long since have ceased to fester in San Francisco had the policies which he had sought to implement only been followed. ${ }^{248}$ That they had not been he attributed to the ignorance of the Chinese and the avarice of the city's commercial interests, the latter

243. Telegram from Governor Gage to President McKinley, June 16, 1900, in Appendix, Special Health Commissioners' Report at 17-18 (cited in note 220).

244. San Francisco Examiner, June 19, 1900, at 8, col. 23.

245. Id.

246. See slip opinion, Wong Wai case file.

247. Kinyoun's remarks were reprinted in the August 1901 issue of Occidental Medical Times.

248. Id. at 15. 
classes aided and abetted by an unscrupulous press and short-sighted or self-seeking politicians.

The speech was liberally salted with the rhetoric of racial superiority that characterized so much medical opinion at the time. ${ }^{249}$ The Chinese, he declared, were a hopelessly alien and, he implied, inferior race, who combined a contempt for modern medical science ("the undertaker's services appear to be held in higher esteem [among them] than those of the disciple of Aesculapius" ${ }^{250}$ ) with an unexcelled capacity for craftiness and deceit. ${ }^{251} \mathrm{He}$ was, he said, at the point of stating that plague would continue to exist in San Francisco until the "pest hole" known as Chinatown was "depopulated and destroyed." 252 Like a previous spokesman for the public health community, he pointed with admiration to the example of what had happened in Honolulu's Chinatown, where public health officials had adopted the practice of burning infected houses and where "fortunate circumstances" had caused one deliberately set blaze to go out of control and spread to the entire district. He wondered aloud whether the Caucasian community would ever muster the nerve for such drastic measures. ${ }^{253}$

Kinyoun clearly believed, however, that elements in the Caucasian community had been chiefly responsible for sabotaging the well-laid plans of the Marine Hospital Service and the city Board of Health. For these he reserved his most withering remarks. Since time immemorial, he noted, announcement of the presence of plague in a community and of measures to deal with it had been resented by the commercial classes, heedless of the medical realities and concerned only about the effect of such an announcement on trade and on their pocketbooks. He compared the actions of the San Francisco business classes with those of the businessmen of Holland, who in the 17th century had successfully opposed every effort by the health authorities of that country to deal with an incipient plague outbreak. "What do these interests care," he asked, "for life, health, and happiness of the people so long as the usual percentages are gathered into their spacious maws?"254 These commercial interests found ready allies among politicians, he added, who did not want the reputation of the state besmirched by allegations of epidemic disease even if the allegations were true.

The governor of the state he accused of a special cynicism in this regard, noting that he had been reported as saying: "It matters not how

249. See J. Haller, Outcasts from Evolution (1971).

250. Id at 4.

251. Id. at 14.

252. Id at 10 .

253. Id at 10-11. A wonderful scheme, of course, for insuring the widest possible dissemination of the disease.

254. Id. at 9. 
many Chinese are killed by Chinese, so long as the Chinese do not kill whites." 255 Then there was the popular press, which aided and abetted the plans of the commercial men and the politicians. Any responsible health officer who sought to do his duty must expect, he said, to become a target of every form of vilification by "the subsidized press." 256 He had strong words of censure too for his colleagues in the medical profession. It was one thing to entertain differences of opinion initially about a diagnosis. It was quite another to persist in an opinion when the countervailing evidence was quite indisputable. ${ }^{257}$ The picture Kinyoun gave was that of a small group of beleaguered men of science fighting a lonely battle against a united front of ignorance, selfishness, and incompetence.

Kinyoun's portrait was certainly overdrawn. Not all of the San Francisco business community opposed the health authorities' plans. Quite the contrary. As noted above, prominent local merchants were present at the mid-May meetings where it was first settled that the Chinese should be inoculated. Businessmen also were among the chief instigators of the second quarantine imposed on Chinatown. (Indeed, they raised some $\$ 30,000$ to fund the operation.) There was every reason for the commercial men to see these steps as a highly effective way of assuring the world outside that the plague problem was confined strictly to Chinatown, thereby preserving the commercial reputation of the rest of the city. Nor were the media completely united against him. Some papers enthusiastically supported his efforts and those of the Board of Health. Nor, finally, was he bereft entirely of political support. The governor may have opposed him, but the mayor was a staunch and steadfast ally as were the majority of the board of supervisors. He also had considerable support in local political circles outside San Francisco. (Sacramento is a good example.) And of course at no point did those Caucasians who were opposed to the health authorities prevent them from doing exactly what they wanted to do.

Nonetheless, having said all of this, there is certainly a measure of justice in his complaint. Many leaders of Caucasian opinion did take a head-in-the-sand attitude throughout the whole plague episode. They did in fact seem quite prepared to resort to any lengths, including self-deception, to prevent it being suggested that plague existed in San Francisco, and the personal attacks on Kinyoun and others were at times shameful. One cannot help feeling a measure of sympathy for them. But any sympathy that one might feel for them must be dwarfed by the sympathy one must feel for those at whom their efforts were directed, the Chinese inhabitants of the city. If Kinyoun felt beleaguered, his beleaguerment paled

255. Id.

256. Id.

257. Id. at 9. 
in comparison to that which the average Chinese must have felt in the face of the coercive actions being proposed. And in the final analysis it was of course neither the commercial classes nor the governor nor the men of the press, but rather the Chinese and Judge Morrow who were responsible for frustrating Surgeon Kinyoun's plans. And for eminently good reason.

It seems safe to say that any San Francisco ethnic group, any district of the city, would have felt deeply threatened by and would have resisted the measures-inoculation with an experimental vaccine, immurement in a confined area - that Kinyoun and the others were proposing for the Chinese. That the Chinese, given the background of a half-century of special legislation and of mistreatment at the hands of officialdom, should have seen them as particularly menacing and should have been even more determined to resist is not surprising. They had come to assume that official actions aimed especially at them were not motivated by good will or solicitude for their interests. And public officials, with their steady stream of hostile and insensitive invective, did nothing during the early weeks of the plague outbreak to disabuse them of these assumptions.

The path of resistance that the Chinese chose was the only one that was open to them, and it was one that they had trod many times before. Being denied the privilege of naturalization and thus access to the franchise, they had no political leverage in the normal sense of the term. But they were not completely bereft of power. At a comparatively early date in their immigration, the Chinese realized how the courts or, to be more precise, judicial review, could be used to frustrate the Sinophobic impulses of the Caucasian majority, and they learned to repair to them when their interests were threatened. The Chinese had also recognized at an early date that even with law and right on one's side, one's chances of vindicating one's claims are immensely strengthened by the assistance of able and effective counsel, so they formed the habit of engaging the best legal talent they could find to represent them. They could afford to indulge in this practice not so much because there was a ready supply of talented lawyers sympathetic to their cause, but rather because they possessed the resources to pay for high-quality legal services. The Chinese community was not a wealthy one, but it was not impoverished either. Most members were gainfully employed. There was a thriving merchant class, made up in the main of small entrepreneurs. When members of the community pooled their resources, as they were wont to do, these could amount to a considerable war chest.

What counsel for the Chinese were able to demonstrate to the court in Wong Wai and Jew Ho was that the health measures devised by Wyman, Kinyoun, and their local counterparts were, in terms of then prevalent scientific understandings, thoroughly arbitrary. They amounted, in fact, to a caricature of sensible public health policy. Compulsory inoculation 
with the Haffkine vaccine was made to apply not just to those who lived in the district thought to be infected with the disease, but to all the Chinese inhabitants of the city and not just to the Chinese, but to the Japanese as well. Bubonic plague was supposed by all to be an easily communicable disease, but the Asian inhabitants of San Francisco, while barred from leaving the city unless inoculated, were, under the first set of measures decided on by the health authorities, allowed to move about freely within the city and to intermingle with other residents. Under the second set, the Chinese, sick and healthy alike, were confined within a small quarter, presumably thus greatly enhancing their chances of contracting the disease.

There was arbitrariness on smaller points as well. The surgeon general had issued instructions that the Haffkine vaccine was not to be used on persons about to leave a plague-affected area or on those who might have been in contact with plague victims and who might therefore have been exposed to the danger of infection, but his instructions to Kinyoun and the local health authorities included no such caveat, and the inoculation plan as administered seems to have made no such distinction. The health authorities' plans involved unprecedented interferences with the right of personal liberty. As such they required justification. But their arbitrariness was fatal to their claim to justification.

But the measures were constitutionally infirm for a much more important reason than the fact that they arbitrarily interfered with general personal liberties. The court became convinced that the arbitrariness of the measures was not simply the product of some failure of analysis of the available information or of too hasty a process of deliberation-though it was clear that these failings did contribute to the decision. It was rather much more the product of deep-seated racial stereotyping and of a fair amount of racial malice on the part of the officials involved. They were directed against the Asian population for no other reason than race. The court was thus easily able to assimilate them to that string of other measures aimed at the Chinese as a class that this very federal court had had occasion in years past to nullify on grounds that they conflicted with the due process or equal protection clauses of the Fourteenth Amendment, with federal law, or with treaty.

At the same time Judge Morrow, even while striking down the health authorities' plans and expressing his own skepticism that plague existed, made clear that they should have full power to isolate individuals suspected of having the disease and should otherwise be shown great deference in developing other measures for dealing with the emergency they thought existed. The court may not have been a font of scientific wisdom (the health authorities hardly had a monopoly on the subject themselves) but, like other American courts before and since, it proved itself a more 
than decent mediator between the civil liberties of the individual and the needs of society at large.

Some five years after the Circuit Court for the Northern District of California handed down its rulings in Wong Wai and Jew Ho, the Supreme Court of the United States spoke authoritatively for the first time on the extent of the police power in the matter of public health regulation. The issue before the tribunal in Jacobson $v$. Massachusetts ${ }^{258}$ was the validity of a Massachusetts statute empowering local boards of health to require compulsory smallpox vaccination if it deemed such a measure necessary to protect the public health. Sweeping aside arguments by the plaintiff in error to the contrary, the court held that compulsory vaccination laws of the sort before it were reasonable exercises of the police power and were not in derogation of any rights secured by the federal Constitution. It also confirmed that local authorities had broad discretion in meeting health emergencies. In reaching its decision the court noted that for nearly a century most members of the medical profession had regarded vaccination as an effective preventive against smallpox, and it seems clear that this fact eased the court's way to its conclusion. The court did make a point of saying that "an acknowledged power of a local community to protect itself against an epidemic threatening the safety of all, might be exercised in particular circumstances and in reference to particular persons in such an arbitrary, unreasonable manner, or might go so far beyond what was reasonably required for the safety of the public, as to authorize or compel the courts to interfere for the protection of such persons." 259 There had been reference to Wong Wai and Jew Ho in the course of oral argument, ${ }^{260}$ but the court did not say whether it had these cases in mind in issuing this proviso. In the years since Jacobson no public health measures comparable to those initiated by the San Francisco health authorities in 1900 have ever come before the Supreme Court or, to my knowledge, any other American tribunal for review.

\section{EPILOGUE}

A final word seems in order on the course of events in San Francisco following the rulings in Wong Wai and Jew Ho. Plague took its first Caucasian victim on August 11, 1900 and continued to smolder during the months immediately following the Wong Wai and Jew Ho decisions, taking on average one victim every 10 to 14 days, almost all of them Chinese. ${ }^{261}$

258. 197 U.S. 11 (1905).

259. Id at 28.

260. Id. at 20-21.

261. Except where otherwise indicated, the chronicle of events in this epilogue is taken from V. Link, A History of Plague in the United States of America 5-11 (1955). 
In December of 1900 the chief of the Division of Domestic Quarantine of the Marine Hospital Service was dispatched to San Francisco to supervise federal efforts. One of his first decisions was to recommend the establishment of what now would be called a "blue ribbon" national commission to establish once and for all whether plague existed in San Francisco. In early January the secretary of the treasury established such a commission consisting of three eminent biological scientists: Professors Simon Flexner of the University of Pennsylvania, F. G. Novy of the University of Michigan, and L. F. Barker of the University of Chicago. The commission arrived in San Francisco at the end of the month and immediately began its investigation. It received full cooperation from city authorities and from the Chinese Six Companies, which assisted the commission in gaining access to the sick and the dead in the Chinese quarter, ${ }^{262}$ but only the most minimal support from the governor, who manifested throughout the deepest suspicion toward it. The commission spent two weeks doing its work and during that time was able to conduct bacteriological examinations on the body tissues of 13 dead Chinese and was able to confirm that six of these had in fact died of bubonic plague. ${ }^{263}$ Inasmuch as the commission's charge was narrow - it was simply to determine the existence or nonexistence of bubonic plague in San Francisco-it limited its findings to this and said nothing about the measures that had been adopted to deal with the disease in the past or about what measures it thought ought to be adopted in the future.

In the wake of the commission's report national, local, and state officials, the last group grudgingly, agreed on the principal points of a public health offensive aimed at eradicating plague from Chinatown. It was but an intensive version of what had gone before, with emphasis placed on the cleansing and fumigation of houses and the disinfection of personal effects. These measures, completed in June, had no impact on the disease, which continued to take victims at about the same rate it had in the past. In November 1902 the San Francisco Board of Health for the first time employed three men to begin to trap rats in Chinatown, but these efforts do not seem to have been pursued very systematically or very vigorously. In early February 1904 federal, city, and state health authorities adopted a resolution urging the rat-proofing of buildings in Chinatown and a campaign of rat-proofing got underway. But the disease had already about run its course. On February 29, it claimed its last human victim. The final tally of the epidemic of bubonic plague in San Francisco: 121 cases and 113 deaths, all but a handful Chinese.

Some three years after the conclusion of the first epidemic a second

262. The Report of the Government Commission on the Existence of Plague in San Francisco, reprint in 15 Occidental Medical Times, no. 4, April 1901, at 102-3.

263. Id. at 117. 
outbreak of bubonic plague began in San Francisco. It lasted approximately a year and a half, produced 160 cases of the disease and 78 deaths. Virtually all the victims were Caucasians. ${ }^{264}$ During this second outbreak, unlike the first, the principal efforts of the health authorities were directed at the trapping and extermination of rats. ${ }^{265}$ No thought appears to have been given to quarantine or the use of the Haffkine prophylactic vaccine as anti-plague measures.

264. W. M. Dickie, Plague in California, 1900-1925 (pamphlet), reprinted from Proceedings of the Conference of State and Provincial Health Authorities of North America 30-32 (1926).

265. See F. M. Todd, Eradicating Plague from San Francisco (report of Citizens Health Committee, 1909). It will be noted that, notwithstanding the focus of the authorities on the killing of rats and the rat-proofing of buildings, this plague episode claimed a large number of victims, thus illustrating how difficult a disease plague is to combat. 
HeinOnline -- 13 Law \& Soc. Inquiry 5141988 